\title{
Non-Coding RNAs in the Brain-Heart Axis: The Case of Parkinson's Disease
}

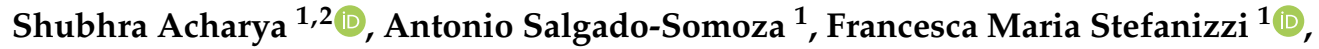 \\ Andrew I. Lumley ${ }^{1}{ }^{1}$, Lu Zhang ${ }^{1}$, Enrico Glaab ${ }^{3}$, Patrick May ${ }^{3}{ }^{\circledR}$ and Yvan Devaux ${ }^{1, *}$ (C) \\ 1 Cardiovascular Research Unit, Department of Population Health, Luxembourg Institute of Health, \\ L-1445 Strassen, Luxembourg; Shubhra.Acharya@lih.lu (S.A.); Antonio.SalgadoSomoza@lih.lu (A.S.-S.); \\ FrancescaMaria.Stefanizzi@lih.lu (F.M.S.); andrew.lumley@lih.lu (A.I.L.); lu.zhang@lih.lu (L.Z.) \\ 2 Faculty of Science, Technology and Medicine, University of Luxembourg, \\ L-4365 Esch-sur-Alzette, Luxembourg \\ 3 Luxembourg Centre for Systems Biomedicine, University of Luxembourg, \\ L-4365 Esch-sur-Alzette, Luxembourg; enrico.glaab@uni.lu (E.G.); patrick.may@uni.lu (P.M.) \\ * Correspondence: yvan.devaux@lih.lu; Tel.: +352-26970-300
}

Received: 16 July 2020; Accepted: 2 September 2020; Published: 6 September 2020

\begin{abstract}
Parkinson's disease (PD) is a complex and heterogeneous disorder involving multiple genetic and environmental influences. Although a wide range of PD risk factors and clinical markers for the symptomatic motor stage of the disease have been identified, there are still no reliable biomarkers available for the early pre-motor phase of $\mathrm{PD}$ and for predicting disease progression. High-throughput RNA-based biomarker profiling and modeling may provide a means to exploit the joint information content from a multitude of markers to derive diagnostic and prognostic signatures. In the field of PD biomarker research, currently, no clinically validated RNA-based biomarker models are available, but previous studies reported several significantly disease-associated changes in RNA abundances and activities in multiple human tissues and body fluids. Here, we review the current knowledge of the regulation and function of non-coding RNAs in PD, focusing on microRNAs, long non-coding RNAs, and circular RNAs. Since there is growing evidence for functional interactions between the heart and the brain, we discuss the benefits of studying the role of non-coding RNAs in organ interactions when deciphering the complex regulatory networks involved in PD progression. We finally review important concepts of harmonization and curation of high throughput datasets, and we discuss the potential of systems biomedicine to derive and evaluate RNA biomarker signatures from high-throughput expression data.
\end{abstract}

Keywords: Parkinson's disease; brain; heart; biomarkers; non-coding RNAs; data science; systems biomedicine; artificial intelligence

\section{Introduction}

Parkinsonian disorders are considered the second most common neurological diseases in humans [1]. Currently, more than 1.2 million people across Europe have Parkinson's disease (PD). Taking into account the aging of the population due to the extension of life expectancy, it is predicted that the prevalence of PD will almost double in the next 30 years [2].

The most recognizable symptom of the disease is the presence of tremors, although the disease could be manifested with bradykinesia and other non-motor symptoms such as the accumulation of an aberrant form of alpha-synuclein or the mitochondrial dysfunction [3]. This symptomatology arises after the loss of dopaminergic neurons in specific areas of the brain, like the motor cortex, the substantia nigra, and the thalamus. The underlying pathology denotes neurodegeneration in specific areas of the 
brain that evokes the tremors, which are responsible for several degrees of disability of the patients. These areas are mainly occupied by dopaminergic neurons, with PD patients presenting defects in the production of the essential neurotransmitter produced by this cell subpopulation, dopamine. Thus, many of the treatments for PD involve the restoration of dopamine levels in the brain, either with the addition of an upstream metabolite or affecting the recycling of dopamine (increasing its availability in the affected neurons) [4].

L-Dopa is a treatment of choice for most PD patients, although it has deleterious side effects in the cardiovascular system, such as aortic stiffness and diastolic function [5]. Some PD patients show other cardiac abnormalities which can lead to sudden cardiac death [6]. Moreover, the complexity of the disease is exacerbated by an important inflammatory component [7-11].

Despite the significant progress in the understanding of the mechanisms leading to PD, the clinical characterization of patients remains challenging [12]. The main hurdle to be overcome is the complexity of the phenotypes, combining several motor and non-motor symptoms and ranging from the early onset of the disease to the advanced stages. Parkinsonian disorders englobe not only PD but also Lewy body disease and other atypical parkinsonian syndromes that represent a challenge for differential diagnosis in the earlier stages [13-15]. In addition, the classification of advanced stages of PD involves a complicated combination of clinical, behavioral, and motor parameters into a single scale recommended by the International Parkinson and Movement Disorder Society (MDS-UPDRS scale) to determine the extent of the disease progression [16]. PD is diagnosed through clinical tests, including extensive neurological and physical examination [17], and post-mortem neurological examination is necessary for disease confirmation [18]. Being able to identify novel methods to accurately diagnose and risk-stratify PD patients may help to move towards personalized healthcare. New biomarkers may help both to diagnose, risk stratify, and prognosticate PD patients at an early stage of the disease.

Due to their presence and relative stability in the bloodstream-often packed in extracellular vesicles or exosomes-non-coding RNAs appeared as potential disease markers [19]. Since non-coding RNAs affect multiple biological pathways leading to disease development and progression, they are also promising therapeutic targets [20]. Several studies reported a permeability of the brain-blood barrier in PD patients [21-24], which suggests that non-coding RNAs released from the brain into the blood may serve as biomarkers in these patients. Non-coding RNAs are arbitrarily classified in two groups depending on their length. The widely investigated microRNAs (miRNAs) are 20-22 nucleotides long, small RNA molecules known to downregulate the expression on protein-coding RNAs (messenger RNAs). Long non-coding RNAs (lncRNAs) usually display a nucleotide sequence of more than 200 nucleotides, and regulate gene expression through diverse mechanisms, mostly at the epigenetic level [25]. LncRNAs are present in the cells and in the extracellular compartment under either a linear or a circular form. In the latter case, they are named circular RNAs (circRNAs).

This review article presents an overview of the knowledge of the role of non-coding RNAs in PD, focusing on the interactions between the brain and the heart.

\section{MicroRNAs}

\subsection{Regulation of miRNAs in Parkinson's Disease}

Table 1 gathers the current knowledge of the regulation of miRNAs in brain and body fluid samples of PD patients. In the exploration of new biomarkers of neurodegenerative diseases in body fluids, the logic drives the search to the cerebrospinal fluid (CSF) due to its proximity with neurons. Moreover, the study of CSF overcomes the issue of potential low permeability of the blood-brain barrier, hampering the release of indicators of brain damage into the bloodstream. In this regard, CSF levels of miR-205 and miR-24 were different between PD patients and non-neurological controls [26]. However, in another study, miR-24 expression levels in CSF were stable between PD patients and controls and was even used as the internal control in quantitative RT-PCR experiments [27]. In this study, three miRNAs were upregulated in PD patients as compared to controls: miR144-5p, miR-200a-3p, 
and miR-542-5p [27]. In yet another study, miRNA profiles in exosomes of CSF samples from PD patients and controls were generated using microarrays. Several miRNAs showed an upregulation (miR-153, miR-409-3p, miR-10a-5p, let-7g3p, miR-136-3p, and miR-433), others were downregulated (miR-1 and miR-19b-3p) in PD patients compared to controls [28]. Using a PCR array, miR-4274 was identified as a candidate marker for the diagnosis of PD versus idiopathic normal pressure hydrocephalus (a condition with similar symptomatology) [29]. Unfortunately, these studies included less than 50 patients or controls per group, and are therefore underpowered. The results have to be considered with caution and need independent validation in adequately sized cohorts. Nevertheless, these studies have the merit of having uncovered the regulation of miRNA expression levels in CSF of PD patients. The difficulty of obtaining CSF hampers the clinical applicability of these miRNAs.

Table 1. Regulation of miRNAs in body fluid samples from PD patients.

\begin{tabular}{|c|c|c|c|c|}
\hline miRNA & Regulation & No. of Samples & Sample Type & Reference \\
\hline $\begin{array}{l}\text { miR-205 } \\
\text { miR-24 * }\end{array}$ & $\begin{array}{l}\uparrow \\
\downarrow\end{array}$ & 28 PD vs. 28 controls & CSF & [26] \\
\hline $\begin{array}{l}\operatorname{miR}-144-5 p \\
\text { miR-200a-3p } \\
\text { miR-542-5p }\end{array}$ & $\begin{array}{l}\uparrow \\
\uparrow \\
\uparrow\end{array}$ & 44 PD vs. 42 controls & CSF & [27] \\
\hline $\begin{array}{l}\text { miR-153* } \\
\text { miR-409-3p * } \\
\text { miR-10a-5p } \\
\text { let-7g3p } \\
\text { miR-136-3p } \\
\text { miR-433 * } \\
\text { miR-30b } \\
\text { miR-1 } \\
\text { miR-19b-3p }\end{array}$ & $\begin{array}{l}\uparrow \\
\uparrow \\
\uparrow \\
\uparrow \\
\uparrow \\
\uparrow \\
\uparrow \\
\downarrow \\
\downarrow\end{array}$ & 47 PD vs. 27 controls & CSF Exosomes & [28] \\
\hline $\operatorname{miR}-4274$ & $\downarrow$ & 28 PD vs. 6 controls & CSF & [29] \\
\hline $\operatorname{miR}-626^{*}$ & $\downarrow$ & 20 PD vs. 27 controls & CSF & [30] \\
\hline $\begin{array}{l}\operatorname{miR}-24 * \\
\text { miR-195 } \\
\text { miR-19b }\end{array}$ & $\begin{array}{l}\uparrow \\
\uparrow \\
\downarrow\end{array}$ & 109 PD vs. 40 controls & Serum Exosomes & [31] \\
\hline $\begin{array}{l}\operatorname{miR}-335-5 p \\
\text { miR-3613-3p } \\
\text { miR-6865-3p }\end{array}$ & $\begin{array}{l}\uparrow \\
\uparrow \\
\uparrow\end{array}$ & 16 PD vs. 8 controls & Serum & {$[32]$} \\
\hline miR-150 & $\downarrow$ & 80 PD vs. 60 controls & Serum & [33] \\
\hline $\operatorname{miR}-29 \mathrm{c} *$ & $\uparrow$ & 51 PD vs. 20 controls & Serum & [34] \\
\hline $\begin{array}{l}\text { miR-146a } \\
\text { miR-335-3 } \\
\text { miR-335-5p * }\end{array}$ & $\begin{array}{l}\downarrow \\
\downarrow \\
\downarrow\end{array}$ & 85 PD vs. 40 controls & Serum & [35] \\
\hline $\begin{array}{l}\text { miR-141 } \\
\text { miR-214 } \\
\text { miR-146b-5p } \\
\text { miR-193a-3p }\end{array}$ & $\begin{array}{l}\downarrow \\
\downarrow \\
\downarrow \\
\downarrow\end{array}$ & 169 PD vs. 180 Controls & Serum & {$[36]$} \\
\hline miR-221 & $\downarrow$ & 138 PD vs. 112 controls & Serum & [37] \\
\hline miR-29 & $\downarrow$ & 80 PD vs. 80 controls & Serum & [38] \\
\hline
\end{tabular}


Table 1. Cont.

\begin{tabular}{|c|c|c|c|c|}
\hline miRNA & Regulation & No. of Samples & Sample Type & Reference \\
\hline $\operatorname{miR}-222$ * & $\downarrow$ & \multirow{3}{*}{42 PD vs. 30 controls } & \multirow{3}{*}{ Plasma } & \multirow{3}{*}{ [39] } \\
\hline $\operatorname{miR}-505$ * & $\downarrow$ & & & \\
\hline $\operatorname{miR}-626^{*}$ & $\downarrow$ & & & \\
\hline miR-331-5p * & $\uparrow$ & 31 PD vs. 25 controls & Plasma & [40] \\
\hline miR-124 & $\downarrow$ & \multirow{2}{*}{60 PD vs. 60 controls } & \multirow{2}{*}{ Plasma } & \multirow{2}{*}[41]{} \\
\hline miR-137 & $\uparrow$ & & & \\
\hline $\operatorname{miR}-30 a-5 p$ & $\uparrow$ & 60 PD vs. 60 controls & Plasma & [42] \\
\hline miR-105-5p & $\uparrow$ & 319 PD vs. 273 controls & Plasma & [43] \\
\hline $\operatorname{miR}-433$ * & $\downarrow$ & \multirow{2}{*}{46 PD vs. 49 controls } & \multirow{2}{*}{ Plasma } & \multirow{2}{*}[44]{} \\
\hline $\operatorname{miR}-133 b$ & $\downarrow$ & & & \\
\hline miR-27a & $\uparrow$ & \multirow{5}{*}{25 PD vs. 25 controls } & \multirow{5}{*}{ Plasma } & \multirow{5}{*}{ [45] } \\
\hline Let-7a & $\downarrow$ & & & \\
\hline Let-7f & $\downarrow$ & & & \\
\hline miR-142-3p & $\downarrow$ & & & \\
\hline $\operatorname{miR}-222 *$ & $\downarrow$ & & & \\
\hline miR-331-5p & $\uparrow \uparrow$ & \multirow{2}{*}{52 PD vs. 48 controls } & \multirow{2}{*}{ Plasma/exosomes } & \multirow{2}{*}{ [46] } \\
\hline $\operatorname{miR}-505 *$ & $\uparrow$ & & & \\
\hline $\operatorname{miR}-132$ * & $\uparrow$ & 269 PD vs. 222 controls & Plasma & [47] \\
\hline miR-7-5p & $\uparrow \uparrow$ & \multirow{20}{*}{$\begin{array}{l}99 \text { Idiopathic PD vs. } 101 \\
\text { controls, } 27 \text { patients with } \\
\text { GBA mutations vs. } 101 \\
\text { controls and } 26 \\
\text { SNCA-A53T mutation } \\
\text { carriers vs. } 101 \text { controls }\end{array}$} & \multirow{20}{*}{ Plasma } & \multirow{20}{*}{ [48] } \\
\hline $\operatorname{miR}-22-3 p^{*}$ & $\uparrow$ & & & \\
\hline miR-124-3p & $\uparrow$ & & & \\
\hline $\operatorname{miR}-136-3 p$ * & $\uparrow$ & & & \\
\hline miR-139-5p & $\uparrow$ & & & \\
\hline miR-330-5p & $\uparrow$ & & & \\
\hline $\operatorname{miR}-433-3 p$ & $\uparrow$ & & & \\
\hline miR-495-3p & $\uparrow$ & & & \\
\hline $\operatorname{miR}-132-3 p$ & $\uparrow$ & & & \\
\hline $\operatorname{miR}-431-3 p$ & $\uparrow$ & & & \\
\hline $\operatorname{miR}-128-3 p$ & $\downarrow$ & & & \\
\hline $\operatorname{miR}-136-3 p$ * & $\downarrow$ & & & \\
\hline miR-154-5p & $\downarrow$ & & & \\
\hline $\operatorname{miR}-323 a-3 p$ & $\downarrow$ & & & \\
\hline miR-338-3p & $\downarrow$ & & & \\
\hline $\operatorname{miR}-382-5 p$ & $\downarrow$ & & & \\
\hline miR-409-3p * & $\downarrow$ & & & \\
\hline $\operatorname{miR}-410-3 p$ & $\downarrow$ & & & \\
\hline $\operatorname{miR}-485-5 p$ & $\downarrow$ & & & \\
\hline $\operatorname{miR}-22-3 p^{*}$ & $\downarrow$ & & & \\
\hline $\operatorname{miR}-29 c^{*}$ & $\uparrow$ & \multirow{3}{*}{13 PD vs 10 non-PD } & \multirow{3}{*}{ PBMC } & \multirow{3}{*}{ [49] } \\
\hline $\operatorname{miR}-424$ & $\uparrow$ & & & \\
\hline $\operatorname{miR}-30 e-5 p$ & $\uparrow$ & & & \\
\hline miR-103a-3p & $\uparrow \uparrow$ & \multirow{3}{*}{46 PD vs. 46 controls } & & \\
\hline miR-30b-5p & $\uparrow$ & & PBMC & [50] \\
\hline $\operatorname{miR}-29 a-3 p$ & $\uparrow$ & & & \\
\hline miR-155-5p & $\uparrow$ & 37 PD ve 43 sontrols & PRMC & [51] \\
\hline $\operatorname{miR}-146-5 p$ & $\downarrow$ & 37 PD vs. 43 controls & PBML & {$[51]$} \\
\hline miR-30c & $\downarrow$ & 19 PD ys 13 controls & PBMC & {$[52]$} \\
\hline miR-26a & $\downarrow$ & 19 PD vs. 13 controls & PBML & \\
\hline
\end{tabular}


Table 1. Cont.

\begin{tabular}{|c|c|c|c|c|}
\hline miRNA & Regulation & No. of Samples & Sample Type & Reference \\
\hline miR-885 & $\uparrow$ & \multirow{3}{*}{36 PD vs. 16 controls } & \multirow{3}{*}{ PBMC } & \multirow{3}{*}{ [53] } \\
\hline miR-17 & $\uparrow$ & & & \\
\hline miR-361 & $\downarrow$ & & & \\
\hline miR-376a & $\downarrow$ & 33 PD vs. 25 controls & PBMC & [54] \\
\hline miR-7 & $\uparrow$ & \multirow{5}{*}{$\begin{array}{l}20 \text { non-medicated PD vs. } \\
18 \text { medicated PD }\end{array}$} & \multirow{5}{*}{$\begin{array}{l}\text { Peripheral blood } \\
\text { lymphocytes }\end{array}$} & \multirow{5}{*}{ [55] } \\
\hline $\operatorname{miR}-9-5 p$ & $\uparrow$ & & & \\
\hline miR-9-3p & $\uparrow$ & & & \\
\hline miR-129 & $\uparrow$ & & & \\
\hline $\operatorname{miR}-132$ * & $\uparrow$ & & & \\
\hline $\operatorname{miR}-223$ & $\downarrow$ & \multirow{2}{*}{83 PD vs. 77 controls } & \multirow{2}{*}{ Saliva } & \multirow{2}{*}{ [56] } \\
\hline $\operatorname{miR}-153$ * & $\downarrow$ & & & \\
\hline miR-874 & $\uparrow$ & \multirow{2}{*}{30 PD vs. 30 controls } & \multirow{2}{*}{ Saliva } & \multirow{2}{*}{ [57] } \\
\hline miR-145-3p & $\uparrow$ & & & \\
\hline
\end{tabular}

The biological fluid of choice to search for miRNA biomarkers is undoubtedly the peripheral blood. Interestingly, a study using both serum and CSF samples from post-mortem PD patients and neurologically normal controls reported the regulation of different miRNAs in body fluids, some of them correlated with disease severity as assessed by Braak stages or by the presence of Lewy bodies [58]. These observations suggest that blood miRNAs may constitute a pool of easily accessible markers of neurological damage in PD patients, as previously described for the neurological outcome of patients with cardiac arrest $[59,60]$. Exosome fractions of serum samples from PD patients and controls were used to address the regulation of 24 miRNAs previously linked to PD [31]. Among these, miR-24 and miR-195 were upregulated, whilst miR-19b was downregulated in PD patients compared to controls [31]. The upregulation of serum levels of miR-24 in this study contrasts with the downregulation observed in the CSF of PD patients from another study [26], supporting the hypothesis that miR-24 might be released from the brain compartment to the blood upon neurological damage associated with PD development. However, as mentioned earlier, CSF levels of miR-24 were found to be stable between PD patients and controls [27], re-emphasizing the need for properly sized patient cohorts and well-defined experimental protocols to draw meaningful conclusions.

Plasma has also been extensively used to search for miRNA biomarkers, although platelets can greatly influence the pool of miRNAs in plasma samples [61]. Using microarrays covering 866 miRNAs, miR-222, miR-505, were found to be differentially expressed and presented an interesting biomarker value for PD [39] (Table 1). A PCR-based study with plasma isolated from $31 \mathrm{PD}$ and 25 controls revealed that miR-331-5p was upregulated in PD patients [40]. In other small-scale studies, miR-124 was downregulated, and miR-137 and miR-30a-5p, were upregulated in plasma samples of PD patients compared to controls [41,42]. In a recent study with 319 idiopathic PD and 273 control samples, plasma levels of miR-105-5p were upregulated in PD samples [43].

Peripheral blood cells contain large amounts of miRNAs and, since their composition in the blood varies depending on the inflammatory status, they constitute another reservoir of potential disease biomarkers [62]. PD is associated with systemic inflammation hence the capacity of the blood cell transcriptome to reveal miRNAs with diagnostic or prognostic value. A microarray study profiled 763 miRNAs in peripheral blood mononuclear cells (PBMC) from 19 PD patients and 13 controls [52]. Four hundred ninety miRNAs were detected, 18 were downregulated while none was significantly upregulated [52]. Expression levels of miR-29c, miR-424, miR-30e5p, miR-103a-3p, miR-30b-5p, miR-29a-3p, and miR-155-5p were upregulated in PBMC isolated from PD subjects as compared to control PBMCs [49-51], while miR-146a-5p was downregulated [51]. A Taqman 
PCR-based study in RNA samples isolated from peripheral lymphocytes of 20 non-medicated PD patients and 18 PD patients under medication revealed that several miRNAs, including brain-enriched miRNAs, were upregulated after treatment (miR-7, miR9-5p, miR-9-3p, miR-129, and miR-132) whilst other miRNAs were unaffected (miR-133b, miR-153, miR-191, miR-346, miR-433, miR-598) [55]. A large scale study used whole blood samples from two different cohorts-PPMI (2802 PD vs. 1538 controls) and NCER-PD (947 PD vs. 493 controls) to highlight the de-regulated small ncRNAs, in particular miRNAs, in PD and demonstrated that the occurrence of their de-regulation is related to disease progression and aging [63]. Whether these changes merely reflect the control of inflammation or the amelioration of the neurological status of the patients remains to be determined.

Recent studies have also shown that saliva can be used as a non-invasive source to detect the change in expression of circulatory miRNAs in patients with PD as compared to controls. Using saliva samples from 83 PD patients and 77 non-neurological controls, Cressatti et al. showed that miR-153 and miR-223 expression levels were significantly downregulated in PD vs. controls [56]. Another RT-qPCR based study on saliva samples from 30 PD patients vs. 30 healthy controls revealed the increased expression of miR-874 and miR-145-3p in PD patients as compared to controls. Additionally, these miRNAs were predicted to target the protein-coding gene DJ1 (PARK7) and are thought to help in the protection against oxidative stress [57]. These studies show that circulatory miRNAs found in various body fluids, such as saliva may act as promising biomarkers for early detection and prognosis of PD.

\subsection{Functional Roles of miRNAs in Parkinson's Disease}

Several investigations were conducted to gain insights into the functional role of miRNAs in PD. MicroRNAs have been shown to regulate a substantial number of mechanisms involved in PD progression (Figure 1). The miR-30 family, whose expression is regulated in CSF and post-mortem brain samples of PD patients $[28,64]$, plays a protective role against neuroinflammation. Indeed, in a PD mouse model, miR-30e reversed the loss of tyrosine hydroxylase (TH), $\alpha$-synuclein aggregation, and motor symptoms induced by MPTP treatment [65]. A study in dopaminergic MN9D cells treated with 6-hydroxydopamine (6-OHDA) showed that increased expression of let-7d reduces cell apoptosis [66]. In another study, using human embryonic kidney epithelial cells (HEK293T) and neuronal SH-SY5Y cells, miR-4639-5p targeted the protein deglycase DJ-1 (also known as PARK7, a PD-related gene), causing oxidative stress and neuronal apoptosis [67]. MiR-7 reduced $\alpha$-synuclein aggregation in human neural progenitor cells [68] and protected against the loss of dopaminergic neurons in MPTP-treated mice [69]. MiR-153 helped in the suppression of $\alpha$-synuclein via mitochondrial reactive oxygen species regulation in HEK293T cells treated with MPP [70]. In a PD mouse model and SH-SY5Y cells treated with MPP, the loss of miR-214 was associated with increased expression of $\alpha$-synuclein [71]. In a miRNA expression profiling study on 19 PD patients and 13 controls, miR-30c and miR-26a were predicted to be the main modulators of the protein ubiquitination pathway [52]. In a study combining investigations in PD patient samples and validation in cell models, miR-205 regulated the expression of PD-related leucine-rich repeat kinase 2 (LRRK2), and prevented the defects in neurite outgrowth in LRRK2 mutant neurons [72]. MiR-181b and miR-124 were shown to be involved in inflammatory response and autophagy in PD models [73,74]. Together, these studies support a significant regulation of PD pathogenesis by miRNAs. 


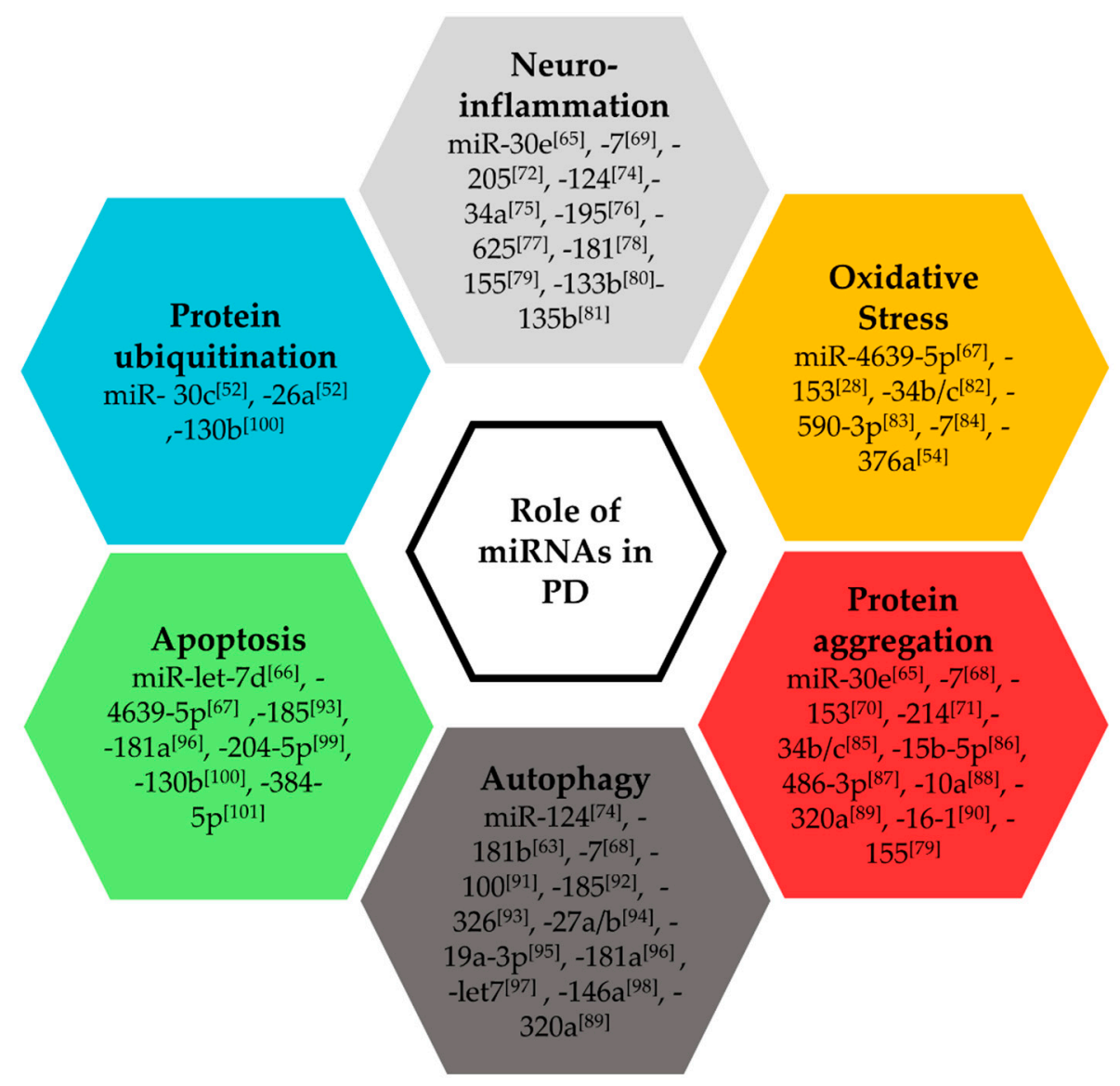

Figure 1. Role of microRNAs in Parkinson's disease [28,52,54,63,65-72,74-101].

\subsection{Therapeutic Potential of miRNAs in Parkinson's Disease}

In addition to their potential as PD biomarkers, miRNAs also have some promise as therapeutic targets. A first approach was explored with a miR-30 shRNA-like molecule, which was able to target LRRK2 [102]. Another miR-based strategy was the creation of artificial mirtrons to target PD-linked LRRK2 and $\alpha$-synuclein messenger RNAs using as a basis the mirtron miR-1224 [103]. An adenovirus-associated vector with a shRNA sequence embedded into a miRNA sequence was able to silence alpha-synuclein in vitro and showed lower toxicity than a similar shRNA under an H1 promoter only [104]. The human cytomegalovirus non-coding Beta2.7 RNA has been proposed as a novel potential therapeutic approach for PD [105]. Another therapeutic approach was carried out in a 6-hydroxydopamine mouse model for PD using nanoparticles coated with miR-124, which ameliorate the PD phenotype at the cellular and motor level [106]. Using the same model together with studies in SH-SY5Y and PC12 cell lines, others reported that the neuroprotective effect of miR-124-3p could be partially due to a decrease of the ANXA5/ERK signaling pathway (which leads to apoptosis) [107]. Therefore, several therapeutic approaches based on miRNAs show promising results that need to be confirmed.

\section{Long Non-Coding RNAs}

\subsection{Regulation of IncRNAs in Parkinson' Disease}

The expression levels of lncRNAs are regulated during normal brain development, as described elsewhere [108,109]. Moreover, there is increasing evidence for the involvement of lncRNAs in the onset and progression of neurodegenerative disorders $[110,111]$. While lncRNAs are canonically expressed under a linear form, a back-splicing event between two or more exons can lead to circularization of 
the linear transcript, generating a circular RNA [112]. To date, relatively few studies have addressed the biomarker value of IncRNAs and circRNAs, even though their biomarker potential has been reported in other diseases, such as cardiovascular disease [113]. The identification of single nucleotide polymorphisms in four lncRNAs in patients with PD suggests that genetic variations within lncRNAs, as well as lncRNAs themselves, may be involved in PD development [114].

There is growing evidence that lncRNAs are regulated in PD (Table 2). In a study using human brain specimens from 20 PD patients and 10 controls, the lncRNA H19 was downregulated whilst lincRNA-p21, MALAT1, SNHG1, and NEAT1 were upregulated in PD [115]. Subsequent studies validated the up-regulation of NEAT1 in the substantia nigra [116] and peripheral blood [117] of PD patients. Another study comparing Substantia nigra samples from PD patients and controls showed a regulation of several lncRNAs, among which AL049437 (deleterious) and AK021630 (protective) were the most regulated ones in a knock-down-based cellular model [118]. In a study using RNA sequencing in leukocytes from PD patients and age- and sex-matched healthy controls, two lncRNAs named U1 and RP11-462G22.1 were regulated, and subsequently validated by PCR [119]. Elsewhere, the differential expression of RP11-462G22.1 could be confirmed when comparing cerebrospinal fluid exosomes from PD patients and healthy controls [28]. Finally, elevated levels of lncRNA NEAT1 have been described in the peripheral blood of PD patients [117].

Table 2. Regulation of lncRNAs in brain and blood samples of PD patients.

\begin{tabular}{|c|c|c|c|c|}
\hline lncRNA & Regulation & No. of Samples & Sample Type & Reference \\
\hline lincRNA-p21 & $\uparrow$ & \multirow{5}{*}{20 PD vs. 10 controls } & \multirow{5}{*}{ Human brain specimens } & \multirow{5}{*}{ [115] } \\
\hline MALAT1 & $\uparrow$ & & & \\
\hline SNHG1 & $\uparrow$ & & & \\
\hline NEAT1 * & $\uparrow$ & & & \\
\hline H19 & $\downarrow$ & & & \\
\hline AL049437 & $\uparrow$ & \multirow{2}{*}{11 PD vs. 14 controls } & \multirow{2}{*}{ Tissue samples } & \multirow{2}{*}{ [118] } \\
\hline AK021630 & $\downarrow$ & & & \\
\hline U1 & $\downarrow$ & \multirow{2}{*}{3 PD vs. 3 controls } & \multirow{2}{*}{ Blood Leukocytes } & \multirow{2}{*}{ [119] } \\
\hline RP11-462G22.1 & $\downarrow$ & & & \\
\hline AC131056.3-001 & $\uparrow$ & \multirow{4}{*}{72 PD vs. 22 controls } & \multirow{4}{*}{ Blood Leukocytes } & \multirow{4}{*}{ [120] } \\
\hline HOTAIRM1 & $\uparrow$ & & & \\
\hline lnc-MOK-6:1 & $\uparrow$ & & & \\
\hline RF01976.1-201 & $\uparrow$ & & & \\
\hline NEAT1 * & $\uparrow$ & 61 PD vs. 42 controls & PBMC & [117] \\
\hline AS-Uchl1 & $\downarrow$ & 68 PD vs. 65 controls & Plasma & [121] \\
\hline
\end{tabular}

PBMC: peripheral blood mononuclear cells; PD: Parkinson's disease; vs.: versus; ${ }^{*}$ IncRNAs found to be differentially expressed in more than one cohort; $\uparrow$ or $\downarrow$ symbolize up or down regulation of lncRNA expression.

\subsection{Functional Roles of IncRNAs in Parkinson's Disease}

The development of PD involves the disturbance of several biological processes important for neuronal survival. Midbrain dopaminergic neurons are the most affected in PD. Thus, the development of neurons and regeneration post neuronal injury plays an important role in the PD processes. Several studies in different model systems have illustrated the roles of lncRNAs in these biological processes, and thus, during the development of PD (Figure 2). Experimental studies showed that the lncRNAs SNGH1 and AL049437 contribute to MPP cytotoxicity in neuronal SH-SY5Y cells [80,122,123]. The lncRNA HOTAIR promotes the PD phenotype induced by MPTP in mice and MPP in SH-SY5Y cells by upregulating the leucine-rich repeat kinase 2 LRRK2, an enzyme involved in PD development [124]. The lncRNA microtubule-associated protein tau antisense 1 (MAPT-AS1) was decreased in different regions of the brain of PD patients as compared to healthy matched controls, and has been proposed as an epigenetic regulator of MAPT expression, which has a pathogenic role in PD [125]. Overexpression of a green fluorescent protein-coupled $\alpha$-synuclein in cells revealed differences in the expression levels of lncRNAs [126]. NEAT1 expression was significantly upregulated in SH-SY5Y cells treated with MPP, 
in a PD mouse model and in the substantia nigra of PD patients, and is involved in the protection against oxidative stress and neuronal injury, and promote autophagy $[116,127,128]$. LncRNA-p21 was shown to regulate the MPP-induced neuronal injury in SH-SY5Y cells via the miR-626-TRMP2 regulatory network [77]. MALAT1 acts as a mediator of cell apoptosis in PD mice and cellular models [129,130]. Further, the downregulation of lncRNA BACE1-AS in a PD rat model was reported to reduce the production of nitric oxide synthase, and thus, prevent oxidative stress [131]. LncRNA HAGLROS is highly expressed in a PD mouse model, as well as in SH-SY5Y cells and is associated with the inhibition of apoptosis and autophagy [91].

Research has highlighted protein ubiquitination as another important process that is disturbed in PD. LncRNA AS-UCHL1, an antisense transcript of the UCHL1 gene, induces UCHL1 translation, thereby showing a protective effect against PD as seen in in vitro and in vivo models [132]. Recent studies have revealed that lncRNA H19, which has previously been studied in different cancers and heart diseases, can also play a protective role against dopaminergic neuronal loss and apoptosis via regulating miR-301b-3p and miR-585-3p, respectively, in PD mice models [133,134].

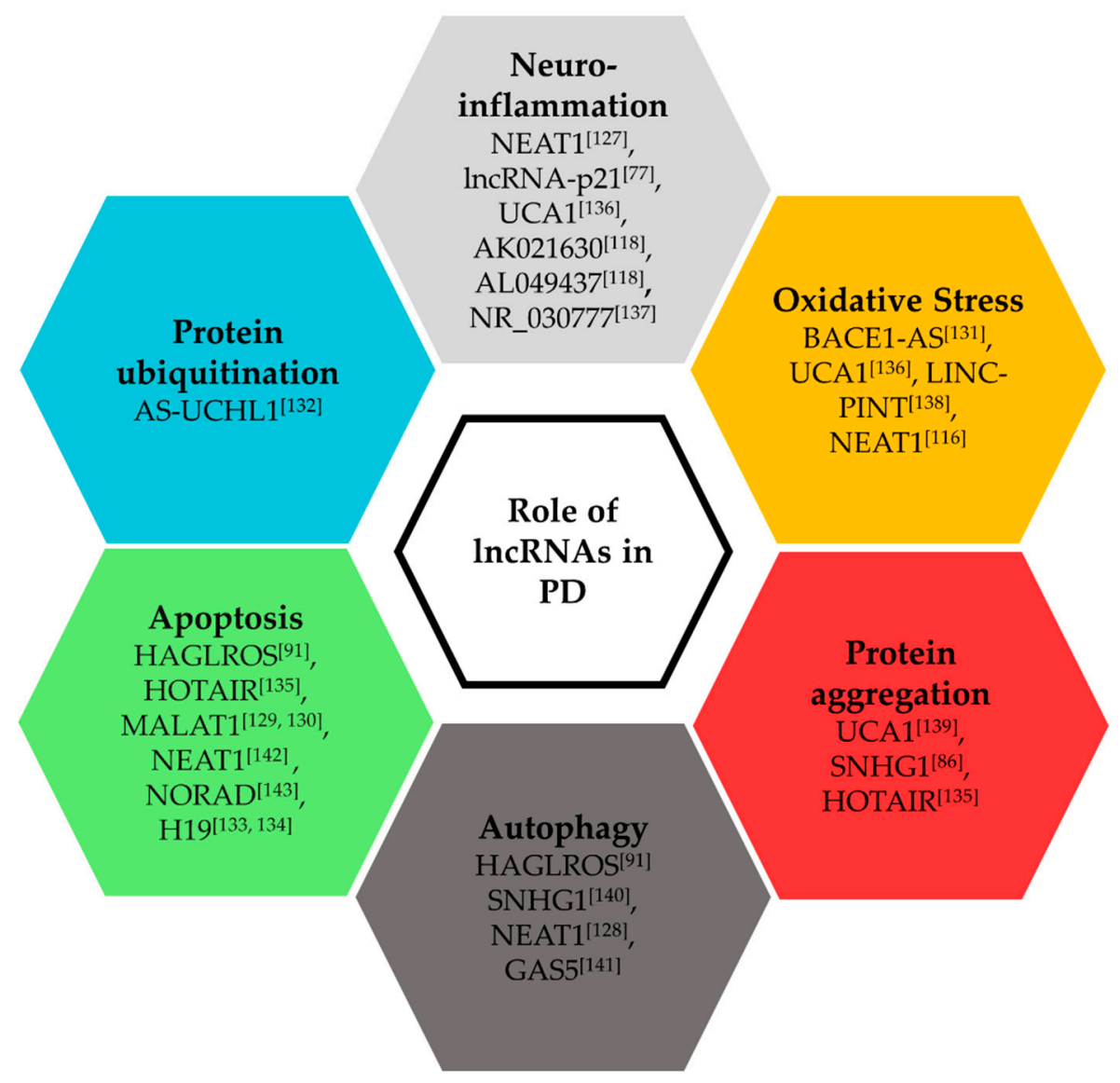

Figure 2. Role of lncRNAs in Parkinson's disease [77,86,91,116,118,127-132,135-143].

As extensively studied and illustrated before, $\alpha$-synuclein protein aggregation is a prominent molecular characteristic of PD. A study in a PD mouse model showed that when the lncRNA HOTAIR was knocked-down, this led to a reduction in the number of $\alpha$-synuclein positive cells, and thus, apoptosis of dopaminergic neurons [135]. Taken together, the above studies suggest that there are various factors that work together in the progression of the disease; therefore, having in-depth knowledge about the role of lncRNAs in these processes could give better insights about the early diagnostic and effective therapeutic measures. 


\section{Circular RNAs}

Circular RNAs are differentialy expressed in various brain and subcellular compartments where they accumulate with age [144]. Since age is a risk factor for neurodegeneration in PD, it is intuitive to think that circRNAs might contribute to the pathogenesis of PD. Dysregulation of gene expression and splicing, affecting, for instance, the expression profiles of circRNAs, often accompanies brain damage. The highly expressed circRNA CDR1-AS appears to be downregulated in the hippocampal CA1 region of patients with sporadic Alzheimer's disease [145]. Due to its high capacity to bind miR-7, which has a protective role in neuronal death [146], it is tempting to speculate that the CDR1-AS-miR-7 axis may also play a role in PD. Another study based on miRNA/SNCA regulation on an MPP treated SH-SY5Y cell model that aimed to delineate the mechanism of pramipexole administration in PD patients showed a downregulation of circSNCA and SNCA expression post pramipexole treatment. The circSNCA downregulation could upregulate miR-7, thereby downregulating the expression of SNCA and eliciting a reduction of cell apoptosis and increased autophagy [147]. A recent study in both mouse and cell models showed circDLGAP4 to be downregulated in both models of PD and that this circRNA could exert neuroprotective effects by regulating miR-134-5p, adding to the importance of circRNA-miRNA interactions in PD pathogenesis [148].

A novel circRNA molecule generated from the zip-2 gene, named circzip-2, was found in a transgenic $C$. elegans model of PD and was shown to be involved in $\alpha$-synuclein protein aggregation and extended lifespan [149]. Further, a circRNA transcriptome profiling study from different brain regions of MPTP-induced PD mouse model revealed differential expression of six circRNAs predicted to be involved in the PD-related pathways. Through an in silico analysis, mmu-circRNA-0003292, and mmu_circRNA_0001320 were predicted to interact with well-known PD-related miRNAs, miR-132, and miR-124, respectively [150]. A recent study on RNA sequencing of brain samples from PD patients and controls also showed the presence of differentially expressed circRNAs in different brain regions. The expression of circSLC8A1 increased in the substantia nigra of PD brain samples and in a PD cell model [151]. Taken together, these studies provide insights into the possible functional role of circRNAs in PD development.

\section{5. tRNA Derived ncRNAs}

t-RNA fragments are a distinct class of small ncRNAs derived from processing of mature t-RNAs in the cytoplasm. These can be (a) t-RNA halves, also known as tiRNAs (30-50 nucleotides long), which are stress-induced and are cleaved from mature t-RNA by the ribonuclease angiogenin (ANG), and (b) tRNA fragments (tRFs) that are 12 to 30 nucleotides long and cleaved from mature tRNA by the endoribonuclease Dicer. These have been found to be dysregulated in different cancers $[152,153]$ and neurological disorders [154]. A study on 3146 PD patients and 7668 controls demonstrated a high prevalence of ANG variants in PD and amyotrophic lateral sclerosis (ALS), showing a possible link between the tRNA processing enzyme-ANG with PD and ALS [155]. A recent analysis of three different data sets (29 patient and 33 control samples from the pre-frontal cortex, CSF samples from 63 patients, and 64 controls, and serum samples from 34 patients and 31 control subjects) revealed that tRFs are differentially abundant in PD vs. controls and were shared among the three different sample types [156]. This study shows that tRFs are detectable in CSF and serum samples and could serve as a potential circulatory biomarker in PD research.

\section{Cardiac Comorbidities in PD}

The development of cardiovascular impairment and loss of cognitive function are major interrelated hallmarks of aging $[157,158]$. PD and cardiovascular diseases (CVD) share common health (diabetes, hypertension, and obesity $[159,160]$ ) and mechanistic (oxidative stress and chronic inflammation [161,162]) risk factors, which supports the need to study these two diseases in concurrence. In this regard, various studies have shown the development of CVDs, such as stroke and acute 
myocardial infarction in patients with PD [163,164]. A large-scale study with 1948 PD patients subdivided into three different age groups showed $36.3 \%$ of patients had circulatory comorbidities, where the prevalence of developing circulation problems was shown to be directly related with age [165]. Another study, including 3367 PD and 823 Parkinsonism patients, showed $42.5 \%$ of sufferers had cerebrovascular disease, and 33.2\% had hypertension co-occurring with PD, where patients with Parkinsonism exhibited higher chances of suffering from comorbidities, which further increased with age [166]. Due to these comorbidities, it is important to carefully select therapeutic approaches for these patients. The development of cardiac valvulopathy in patients with PD undergoing dopamine agonist therapy (drugs-Pergolide and Cabergoline) has been observed to be most common [167,168]. The detrimental effects of Levodopa — the most common drug used to treat PD—on the heart has been studied for years [169]. PD patients showed reduced mean arterial pressure (15\%), cardiac stroke volume (13\%), and cardiac contractility (18\%) after Levodopa administration [170]. Under L-Dopa treatment, patients had aortic stiffness and impaired diastolic function [5]. Administration of the dopamine agonist Pramipexole increased the risk of heart failure [171]. Conversely, Amiodarone, an antiarrhythmic medication, has been shown to have neurotoxic effects associated with tremors and Parkinsonism [172,173]. Cinnarizine and Flunarizine-calcium channel blocking drugs frequently used to treat angina, high blood pressure, and arrhythmia-induced movement disorders, Parkinsonism, and depression in $34 \%$ of patients [174]. Interestingly, PD-associated mitochondrial proteins Parkin, PINK1, DJ-1, LRRK2, and $\alpha$-synuclein (involved in governing neuro-inflammation) are also expressed in the heart [175], yet their potential functions in the heart have not been deeply studied, especially in human. An experimental study reported that Parkin plays a role in cardiac function and left ventricular remodeling in rats subjected to myocardial infarction [176]. Taken together, these observations support the importance of brain-heart interactions in PD and highlight the need for further research in this area to uncover the potential mechanisms.

\section{Non-Coding RNAs in the Brain-Heart Axis in PD}

One angle to investigate the brain-heart interactions in PD is to focus on non-coding RNAs known to be perturbed in either PD or heart diseases. A study with 46 PD subjects showed a significant reduction in circulating levels of miR-133b [44]. MiR-133b is expressed in the brain and is known to regulate the development of midbrain dopaminergic neurons [177]. Interestingly, miR-133b is also regulated after myocardial infarction and dampens reactive oxygen species production $[178,179]$. Therefore, miR-133b has roles both in the brain and the heart. Another example is miR-124, along with miR-124-5p and miR-124-3p, which are known for their protective roles in cardiac injury, angiogenesis, and other heart diseases [180,181]. In addition, miR-124-3p is an efficient prognostication tool for neurological outcome and survival in patients post-cardiac arrest [59]. It has antioxidant properties, protects against neuroinflammation, and regulates several pathways involved in PD progression [71,74,107,182,183]. Hence miR-124-3p establishes functional links between brain and heart diseases. Not only small ncRNAs but also long ncRNAs appear to be involved in brain-heart interactions. Indeed, a recent study showed that the lncRNA MALAT1 is a positive regulator of apoptosis and acts by inhibiting miR-124 levels in SH-SY5Y neuronal cell line and mice PD model [130]. MALAT1 is also known as a positive regulator of cardiomyocyte apoptosis and cardiac fibrosis [184,185]. Furthermore, MALAT1 upregulates $\alpha$-synuclein protein expression in an MPTP-induced PD mouse model and in SH-SY5Y neuronal cells treated with MPP+ [186]. Lastly, MALAT1 promotes apoptosis of MN9D dopaminergic neuronal cells through a mechanism implicating LRRK2 and miR-205-5p [187]. Thus, MALAT1 appears to be a potential target against apoptosis in both heart disease and PD. HOTAIR is another lncRNA known to have prominent roles in PD and heart diseases. It is highly expressed in cardiac tissues and is regulated in plasma and serum samples of patients with congenital heart diseases and acute myocardial infarction $[188,189]$. HOTAIR supports the stability of LRRK2 expression in PD, and its knockdown in MPP-treated SH-SY5Y cells conferred a protective effect against neuroinflammation [190]. HOTAIR promotes cell apoptosis by sponging miR-221 in in vitro and in vivo PD models [191]. These 
studies provide insights into the interplay between the diseased heart and brain and suggest that non-coding RNAs play a role in common pathways governing PD and heart diseases.

\section{Translatable Techniques for Parkinson's Disease}

Through 'bed to bench to bed' work cycles, the close partnership between clinics and research laboratories can aid in the uncovering of novel, sensitive, and reproducible biomarkers. Indeed, the use of many laboratory techniques has expanded our knowledge in recent years and continue to play pivotal roles in Parkinson's clinics. Such techniques as transcriptomics, proteomics, and metabolomics have been able to provide great insight into disease pathogenesis. The applicability of the omics techniques to multiple biological media such as brain tissue, CSF, and blood has allowed uncovering several key processes decisive to PD development-notably related to mitochondrial dysfunction and synaptogenesis [192,193]. Moreover, genome-wide association studies have identified dozens of risk loci for PD, with a recent study uncovering a further 17 [114,194]. The knock-on effects of these discoveries not only have enhanced our understanding of disease pathogenesis but also have been able to suggest novel drug targets. Whilst such studies offer much promise for the future, the use of cutting-edge technology such as CRISPR Cas9 gene editing or induced pluripotent stem cells (iPSCs) have the potential to change the PD landscape today. As an example, iPSCs may be used not only to improve the diagnosis of PD but also to treat this disorder through genetic reprogramming [195].

\section{Available Gene Expression Datasets in Parkinson's Disease}

A non-systematic search of gene expression omnibus (GEO) database [196] for public datasets associated with Parkinson's disease identified 53 gene expression datasets generated from human samples, including whole blood, blood cells, iPSCs, human embryonic stem cells, brain tissues, and neuronal cell lines, using either microarray or RNA sequencing (RNA-seq). These datasets had at least three replicates per group.

Five datasets reveal associations between expression levels of miRNAs and PD (Table 3), supporting their potential involvement in disease progression.

Table 3. GEO datasets reporting associations between miRNAs and Parkinson's disease.

\begin{tabular}{|c|c|c|c|c|}
\hline $\begin{array}{c}\text { GEO } \\
\text { Reference }\end{array}$ & $\begin{array}{c}\text { Profiling } \\
\text { Technique }\end{array}$ & Main Observations & Sample Type & Reference \\
\hline GSE72962 & RNA-seq & $\begin{array}{l}125 \text { miRNAs are regulated in PD } \\
\text { A set of } 29 \text { miRNAs classifies PD }\end{array}$ & $\begin{array}{l}\text { Frozen brain tissue from } \\
\text { pre-frontal cortex of } 29 \mathrm{PD} \\
\text { patients and } 33 \text { controls. }\end{array}$ & [197] \\
\hline GSE16658 & Microarray & $\begin{array}{l}18 \text { miRNAs are regulated in PD } \\
11 \text { miRNAs are over-represented } \\
\text { in pathways linked to PD }\end{array}$ & $\begin{array}{l}\text { PBMCs of } 19 \text { PD patients } \\
\text { and } 13 \text { controls }\end{array}$ & [53] \\
\hline GSE110719 & RNA-seq & $\begin{array}{l}99 \text { miRNAs are regulated in the } \\
\text { substantia nigra of PD patients }\end{array}$ & $\begin{array}{l}\text { Fibroblasts and iPSCs from } \\
6 \text { controls and nine PD } \\
\text { Dopaminergic neurons } \\
\text { from five controls and } \\
\text { six PD. }\end{array}$ & [198] \\
\hline GSE97285 & RNA-seq & $\begin{array}{l}\text { Several groups of miRNAs are } \\
\text { regulated in PD at different } \\
\text { disease progression stages }\end{array}$ & $\begin{array}{l}\text { Brain samples from the } \\
\text { amygdala-14 PD and } \\
14 \text { controls }\end{array}$ & [199] \\
\hline GSE40915 & RNA-seq & $\begin{array}{l}16 \text { miRNAs are regulated in blood } \\
\text { leukocytes of PD } \\
\text { patient's pre-treatment } \\
11 \text { miRNAs are regulated after } \\
\text { brain stimulation, among which } \\
\text { five vary inversely to } \\
\text { disease evolution. }\end{array}$ & $\begin{array}{l}\text { Blood leukocytes from } \\
\text { nine PD and three controls. }\end{array}$ & [200] \\
\hline
\end{tabular}


The microarray and RNA-seq datasets targeting long RNAs were mainly used for protein-coding sequences. A re-analysis of these datasets, starting with the re-annotation of microarray probes [201], and the re-alignment of sequencing reads [202] could provide a source of additional information on the regulation of known, and novel lncRNAs. Bioinformatics tools such as DCC [203] and findCirc [204] applied to RNA-seq datasets could be useful to discover novel circRNAs associated with PD.

\section{Harmonization of High-Throughput Datasets and Clinical Data from Parkinson's Disease Patients}

There are several national and international efforts to harmonize clinical and multi-omics data for PD. The Michael J. Fox Foundation (MJFF) strives to make PD data available to the broader research community. Through their sponsored studies, they have collected or acquired clinical, omics, imaging, genomics, sensor, and patient-reported data. The largest projects are the Parkinson's Progression Markers Initiative (PPMI, http://www.ppmi-info.org/), the MJFF investigation for the New Discovery of Biomarkers (BioFIND, https://biofind.loni.usc.edu/), and the MJFF LRRK2 Cohort Consortium. PPMI is a cohort of 423 de novo idiopathic PD patients, 196 healthy controls, 64 subjects with scans without evidence of dopaminergic deficit, 65 patients with PD risk factors of hyposomnia and sleep disorder, and 645 genetic cases (372 LRRK2, 246 GBA, 27 SNCA mutation carriers). PPMI omics data include genomics, transcriptomics, and DNA methylation data. The Luxembourgish National Centre for Excellence in Research on Parkinson's Disease (NCER-PD) has been created to catalyze research aiming to improve the diagnosis and risk stratification of PD [12]. This may be achieved through the combination of accurate clinical and molecular data obtained from PD patients in order to develop novel biomarker signatures and refine the classification of subtypes of the disease. This is expected to allow an earlier and more specific diagnosis of PD to offer patients better and personalized treatments. A rich set of biospecimen, omics, and clinical data have been collected for 800 patients and 800 healthy controls. NCER-PD harmonizes clinical data captured as electronic case report forms (eCRFs) within a research electronic data capture (RedCAP) that makes it possible to exchange or combine clinical and omics data between PD datasets, such as the DeNoPa dataset [205].

\section{Systems-Level Biomedical Data Mining Applied to the Discovery of RNA Biomarkers of Parkinson's Disease}

\subsection{RNA-Based Computational Biomarker Discovery for PD}

In recent years, due to the widespread use of high-throughput experimental molecular profiling approaches for the study of complex diseases, computational approaches for systems-level biomarker discovery have gained significant importance. Among the omics profiling approaches used in biomarker research, RNA transcriptomics profiling methods, such as RNA-seq or microarrays, provide some of the most popular and effective means for the systems-level study of disease-associated biospecimens, with high coverage of relevant biomolecules.

To explore these data sources effectively, available in silico approaches for biomarker discovery include both domain-agnostic feature selection and machine learning approaches to identify single-molecular markers or combinatorial biomarker signatures, and dedicated, domain-specific systems biology approaches for biomarker modeling. While generic machine learning methods are directly applicable to diverse types of input data, new cellular pathways and network-based biomarker discovery approaches often require more time-consuming, domain-specific data processing, but can provide biomarker models with improved accuracy, robustness and interpretability by exploiting prior biological domain knowledge. To illustrate the potential of these new system-level approaches, in the following chapter, current computational pathways and network analysis methods for RNA-based biomarker modeling are discussed, as well as the first representative applications in PD research. 


\subsection{Pathway- and Network-Based Biomarker Modeling for PD Research}

Statistical and machine learning analyses of omics data often consider all measured biomolecules as independent variables or model their dependencies using correlations. However, RNAs, proteins, and metabolites have functional interrelations, which may only partly be reflected by correlations. Public pathway and molecular interaction databases provide a rich body of prior knowledge on direct physical and regulatory interactions between biomolecules, which can be exploited for systems-level omics analyses.

For this purpose, cellular pathways and networks can be represented at different levels of complexity. Univariate pathway analysis approaches disregard the network topology of cellular processes, and score their alterations using only the list of pathway members as input for over-representation statistics, such as Fisher's exact test, or continuous tests, as implemented in the software tools GSEA [206] or PAGE [207]. More recently, multivariate pathway analysis methods have been proposed, which represent coordinated pathway alterations by aggregating measurement data for all pathway members via dimension reduction approaches into global pathway activity statistics, also called "pathway fingerprints" or "meta-genes". These approaches can provide robust, pathway-level predictive features to fit machine learning models for diagnostic sample classification [208,209].

Since the publicly available pathway definitions do not capture all the experimentally verified molecular interactions in public interaction databases, unbiased network analyses may be applied as a further means to identify systems-level alterations in omics data. The corresponding algorithms investigate entire genome-scale molecular networks to identify sub-networks with coordinated activity changes. They provide more complete coverage of the cellular process alterations than pathway analysis methods, but often lack the interpretability of compact, manually curated pathway definitions [210,211]. Apart from identifying local network perturbations, some of the more recently developed algorithms also enable causal network explorations. This can, for example, be achieved by exploiting prior knowledge on directional regulatory or signaling relationships between biomolecules to infer the most probable upstream molecular network causes for observed downstream changes in omics data [212-215]. In particular, these methods help researchers to identify key transcription factors or regulatory RNAs whose disease-associated alterations may have important pathological or protective downstream effects.

One of the first examples for systems-level molecular pathway analysis of PD was presented in a study integrating transcriptomics and data from genome-wide association studies to determine consensus on disease-associated cellular processes, such as axonal guidance and focal adhesion pathways, through a statistical meta-analysis [216]. Later studies combined pathway enrichment analyses with topological network analysis to identify key miRNA networks altered in PD [217], integrated known PD-associated pathways within a molecular interaction map for visual omics data exploration [218] and applied graph-based network analyses, e.g., to identify shared molecular network alterations between PD and type 2 diabetes [219].

More recently, for the causal network analysis of PD, transcriptomics studies investigating inter-process correlations of individual pathways to determine likely upstream and downstream pathway alterations were presented [220]. Moreover, causal network reconstructions for PD were derived from co-expression analyses [221], and from exploiting prior biological knowledge from canonical networks [222]. These new causal analytical approaches have revealed robust upstream molecular network perturbations in PD, e.g., affecting RNA metabolism [220], with potential applications in biomarker research for early-stage PD.

While these initial representative studies highlight the potential of systems-level pathway/network analyses in PD research, the high heterogeneity of the PD molecular and clinical symptoms, and the limited sample sizes available in previous analyses still pose major challenges in the data analysis and modeling. Large-scale validation studies and meta-analyses across independent cohorts are therefore 
required in the future to substantiate the reported cellular processes alterations in PD and their utility for biomarker modeling.

\section{Conclusions and Future Directions}

Overall, the knowledge on a potential functional role and biomarker value of non-coding RNAs in PD development and progression is relatively scarce. This is especially true for circRNAs for which a deeper understanding of the functional role of their deregulation upon brain damage shall be acquired. In addition, although circRNAs are present in the blood-in leukocytes or encapsulated in extracellular vesicles-, whether they have some potential as PD biomarkers remains to be examined. Although some studies provide insights into the role of non-coding RNAs in the brain-heart axis, a better knowledge of the interactions between these two organs is required. This knowledge can be gained using a combination of high throughput data combined with machine learning analysis. Systems-level pathway and network analyses of transcriptomics data have the potential to reveal new biomarker signatures for PD diagnosis and prognosis. To favor the translation of initial transcriptomics-derived discoveries into clinically relevant diagnostic tests, more extensive collections of RNA profiling data for PD, covering different tissues and body fluids, are required. Cross-cohort analyses, integrating findings from multiple studies, will aid in identifying robust biomarkers. Ultimately, the identification of novel non-coding RNAs involved in PD progression may lead to the development of diagnostic tests or treatments for the patient's benefit.

Author Contributions: Original manuscript drafting (S.A., A.S.-S., F.M.S., A.I.L., L.Z., E.G., P.M., Y.D.). Manuscript editing and proof-reading (S.A., Y.D.). All authors have read and agreed to the published version of the manuscript.

Funding: This work is supported by COST (European Cooperation in Science and Technology) Action EU-CardioRNA CA17129, the National Research Fund of Luxembourg (grants \# C14/BM/8225223 and C17/BM/11613033), the Ministry of Higher Education and Research of Luxembourg, and the Heart Foundation-Daniel Wagner.

Conflicts of Interest: The authors declare no conflict of interest.

$\begin{array}{ll}\text { Abbreviations } & \\ \text { PD } & \text { Parkinson's disease } \\ \text { miRNA } & \text { MicroRNA } \\ \text { lncRNA } & \text { Long non-coding RNA } \\ \text { circRNA } & \text { Circular RNA } \\ \text { CSF } & \text { Cerebrospinal Fluid } \\ \text { PBMC } & \text { Peripheral blood mononuclear cells } \\ \text { PPMI } & \text { Parkinson's Progressive Markers Initiative } \\ \text { NCER-PD } & \text { National Centre of Excellence in Research on Parkinson's Disease } \\ \text { MPTP } & \text { 1-methyl-4-phenyl-1,2,3,6-tetrahydropyridine } \\ \text { MPP } & \text { 1-methyl-4-phenylpyridinium } \\ \text { LRRK2 } & \text { Leucine-rich repeat kinase 2 } \\ \text { HOTAIR } & \text { HOX transcript antisense RNA } \\ \text { NEAT1 } & \text { Nuclear Paraspeckle Assembly Transcript 1 } \\ \text { MALAT1 } & \text { Metastasis Associated Lung Adenocarcinoma Transcript 1 } \\ \text { BACE1-AS } & \text { Beta- Secretase 1 Antisense RNA } \\ \text { HAGLROS } & \text { HAGLR Opposite Strand LncRNA } \\ \text { C. elegans } & \text { Caenorhabditis elegans } \\ \text { GEO } & \text { Gene Expression Omnibus }\end{array}$




\section{References}

1. Rizek, P.; Kumar, N.; Jog, M. An update on the diagnosis and treatment of Parkinson disease. Can. Med. Assoc. J. 2016, 188, 1157-1165. [CrossRef]

2. Bach, J.; Ziegler, U.; Deuschl, G.; Dodel, R.; Doblhammer-Reiter, G. Projected numbers of people with movement disorders in the years 2030 and 2050. Mov. Disord. 2011, 26, 2286-2290. [CrossRef]

3. Antony, P.M.A.; Diederich, N.J.; Krüger, R.; Balling, R. The hallmarks of Parkinson's disease. FEBS J. 2013, 280, 5981-5993. [CrossRef]

4. Meiser, J.; Weindl, D.; Hiller, K. Complexity of dopamine metabolism. Cell Commun. Signal. 2013, 11, 34. [CrossRef] [PubMed]

5. Günaydın, Z.Y.; Özer, F.F.; Karagöz, A.; Bektaş, O.; Karataş, M.B.; Vural, A.; Bayramoğlu, A.; Çelik, A.; Yaman, M. Evaluation of cardiovascular risk in patients with Parkinson disease under levodopa treatment. J. Geriatr. Cardiol. 2016, 13, 75-80.

6. Scorza, F.A.; Fiorini, A.C.; Scorza, C.A.; Finsterer, J. Cardiac abnormalities in Parkinson's disease and Parkinsonism. J. Clin. Neurosci. 2018, 53, 1-5. [CrossRef] [PubMed]

7. Troncoso-Escudero, P.; Parra, A.; Nassif, M.; Vidal, R.L. Outside in: Unraveling the Role of Neuroinflammation in the Progression of Parkinson's Disease. Front. Neurol. 2018, 9, 860. [CrossRef] [PubMed]

8. Metzger, J.M.; Moore, C.F.; Boettcher, C.A.; Brunner, K.G.; Fleddermann, R.A.; Matsoff, H.N.; Resnikoff, H.A.; Bondarenko, V.; Kamp, T.J.; Hacker, T.A.; et al. In vivo imaging of inflammation and oxidative stress in a nonhuman primate model of cardiac sympathetic neurodegeneration. NPJ Parkinson's Dis. 2018, 4, 22. [CrossRef] [PubMed]

9. Labzin, L.I.; Heneka, M.T.; Latz, E. Innate Immunity and Neurodegeneration. Annu. Rev. Med. 2018, 69, 437-449. [CrossRef]

10. King, E.; Thomas, A. Systemic Inflammation in Lewy Body Diseases. Alzheimer Dis. Assoc. Disord. 2017, 31, 346-356. [CrossRef] [PubMed]

11. Ferrari, C.C.; Tarelli, R. Parkinson's disease and systemic inflammation. Parkinsons Dis. 2011, 2011, 436813. [CrossRef] [PubMed]

12. Hipp, G.; Vaillant, M.; Diederich, N.J.; Roomp, K.; Satagopam, V.P.; Banda, P.; Sandt, E.; Mommaerts, K.; Schmitz, S.K.; Longhino, L.; et al. The Luxembourg Parkinson's Study: A Comprehensive Approach for Stratification and Early Diagnosis. Front. Aging Neurosci. 2018, 10, 326. [CrossRef] [PubMed]

13. Ali, K.; Morris, H.R. Parkinson's disease: Chameleons and mimics. Pract. Neurol. 2015, 15, 14-25. [CrossRef]

14. Levin, J.; Kurz, A.; Arzberger, T.; Giese, A.; Höglinger, G.U. The Differential Diagnosis and Treatment of Atypical Parkinsonism. Dtsch. Aerzteblatt Online 2016, 113, 61-69. [CrossRef] [PubMed]

15. Le, W.; Dong, J.; Li, S.; Korczyn, A.D. Can Biomarkers Help the Early Diagnosis of Parkinson's Disease? Neurosci. Bull. 2017, 33, 535-542. [CrossRef] [PubMed]

16. Goetz, C.G.; Tilley, B.C.; Shaftman, S.R.; Stebbins, G.T.; Fahn, S.; Martinez-Martin, P.; Poewe, W.; Sampaio, C.; Stern, M.B.; Dodel, R.; et al. Movement Disorder Society-sponsored revision of the Unified Parkinson's Disease Rating Scale (MDS-UPDRS): Scale presentation and clinimetric testing results. Mov. Disord. 2008, 23, 2129-2170. [CrossRef]

17. Wang, G.; Cui, H.-L.; Liu, J.; Xiao, Q.; Wang, Y.; Ma, J.-F.; Zhou, H.-Y.; Pan, J.; Tan, Y.; Chen, S.; et al. Current approaches for the management of Parkinson's disease in Chinese hospitals: A cross-sectional survey. BMC Neurol. 2018, 18, 122. [CrossRef]

18. Michotte, A. Recent developments in the neuropathological diagnosis of Parkinson's disease and parkinsonism. Acta Neurol. Belg. 2003, 103, 155-158.

19. Goretti, E.; Wagner, D.R.; Devaux, Y. miRNAs as biomarkers of myocardial infarction: A step forward towards personalized medicine? Trends Mol. Med. 2014, 20, 716-725. [CrossRef]

20. Foinquinos, A.; Batkai, S.; Genschel, C.; Viereck, J.; Rump, S.; Gyöngyösi, M.; Traxler, D.; Riesenhuber, M.; Spannbauer, A.; Lukovic, D.; et al. Preclinical development of a miR-132 inhibitor for heart failure treatment. Nat. Commun. 2020, 11, 633. [CrossRef]

21. Lee, H.; Pienaar, I.S. Disruption of the blood-brain barrier in Parkinson's disease: Curse or route to a cure? Front. Biosci. 2014, 19, 272-280. [CrossRef] [PubMed]

22. Gray, M.T.; Woulfe, J.M. Striatal blood-brain barrier permeability in Parkinson's disease. J. Cereb. Blood Flow Metab. 2015, 35, 747-750. [CrossRef] [PubMed] 
23. Desai, B.S.; Monahan, A.J.; Carvey, P.M.; Hendey, B. Blood-brain barrier pathology in Alzheimer's and Parkinson's disease: Implications for drug therapy. Cell Transplant. 2007, 16, 285-299. [CrossRef] [PubMed]

24. Sweeney, M.D.; Sagare, A.P.; Zlokovic, B.V. Blood-brain barrier breakdown in Alzheimer disease and other neurodegenerative disorders. Nat. Rev. Neurol. 2018, 14, 133-150. [CrossRef]

25. Network, T.C.; Devaux, Y.; Zangrando, J.; Schroen, B.; Creemers, E.E.; Pedrazzini, T.; Chang, C.-P.; Dorn, G.W.; Thum, T.; Heymans, S. Long noncoding RNAs in cardiac development and ageing. Nat. Rev. Cardiol. 2015, 12, 415-425. [CrossRef]

26. Marques, T.M.; Kuiperij, H.B.; Bruinsma, I.B.; Van Rumund, A.; Aerts, M.B.; Esselink, R.A.J.; Bloem, B.R.; Verbeek, M.M. MicroRNAs in Cerebrospinal Fluid as Potential Biomarkers for Parkinson's Disease and Multiple System Atrophy. Mol. Neurobiol. 2016, 54, 7736-7745. [CrossRef]

27. Mo, M.; Xiao, Y.; Huang, S.; Cen, L.; Chen, X.; Zhang, L.; Luo, Q.; Li, S.; Yang, X.; Lin, X.; et al. MicroRNA expressing profiles in A53T mutant alpha-synuclein transgenic mice and Parkinsonian. Oncotarget 2016, 8, $15-28$. [CrossRef]

28. Gui, Y.-X.; Liu, H.; Zhang, L.; Lv, W.; Hu, X. Altered microRNA profiles in cerebrospinal fluid exosome in Parkinson disease and Alzheimer disease. Oncotarget 2015, 6, 37043-37053. [CrossRef]

29. Jurjević, I.; Miyajima, M.; Ogino, I.; Akiba, C.; Nakajima, M.; Kondo, A.; Kikkawa, M.; Kanai, M.; Hattori, N.; Arai, H. Decreased Expression of hsa-miR-4274 in Cerebrospinal Fluid of Normal Pressure Hydrocephalus Mimics with Parkinsonian Syndromes. J. Alzheimers Dis. 2017, 56, 317-325. [CrossRef]

30. Qin, L.-X.; Tan, J.-Q.; Zhang, H.-N.; Tang, J.-G.; Jiang, B.; Shen, X.-M.; Tang, B.-S.; Wang, C.-Y. Preliminary study of hsa-miR-626 change in the cerebrospinal fluid of Parkinson's disease patients. J. Clin. Neurosci. 2019, 70, 198-201. [CrossRef]

31. Cao, X.-Y.; Lu, J.-M.; Zhao, Z.-Q.; Li, M.-C.; Lu, T.; An, X.-S.; Xue, L.-J. MicroRNA biomarkers of Parkinson's disease in serum exosome-like microvesicles. Neurosci. Lett. 2017, 644, 94-99. [CrossRef] [PubMed]

32. Patil, K.S.; Basak, I.; Dalen, I.; Hoedt, E.; Lange, J.; Lunde, K.A.; Liu, Y.; Tysnes, O.-B.; Forsgren, L.; Aarsland, D.; et al. Combinatory microRNA serum signatures as classifiers of Parkinson's disease. Park. Relat. Disord. 2019, 64, 202-210. [CrossRef]

33. Li, H.; Yu, L.; Li, M.; Chen, X.; Tian, Q.; Jiang, Y.; Li, N. MicroRNA-150 serves as a diagnostic biomarker and is involved in the inflammatory pathogenesis of Parkinson's disease. Mol. Genet. Genom. Med. 2020, 8, e1189. [CrossRef] [PubMed]

34. Ozdilek, B.; Demircan, B. Serum microRNA expression levels in Turkish patients with Parkinson's disease. Int. J. Neurosci. 2020, 1-9. [CrossRef] [PubMed]

35. Oliveira, S.R.; Dionísio, P.A.; Guedes, L.C.; Gonçalves, N.; Coelho, M.M.; Rosa, M.M.; Amaral, J.D.; Ferreira, J.J.; Rodrigues, C.M.P. Circulating Inflammatory miRNAs Associated with Parkinson's Disease Pathophysiology. Biomolecules 2020, 10, 945. [CrossRef] [PubMed]

36. Dong, H.; Wang, C.; Lu, S.; Yu, C.; Huang, L.; Feng, W.; Xu, H.; Chen, X.; Zen, K.; Yan, Q.; et al. A panel of four decreased serum microRNAs as a novel biomarker for early Parkinson's disease. Biomarkers 2015, 21, 129-137. [CrossRef]

37. Ma, W.; Li, Y.; Wang, C.; Xu, F.; Wang, M.; Liu, Y. Serum miR-221 serves as a biomarker for Parkinson's disease. Cell Biochem. Funct. 2016, 34, 511-515. [CrossRef]

38. Bai, X.; Tang, Y.; Yu, M.; Wu, L.; Liu, F.; Ni, J.; Wang, Z.; Wang, J.; Fei, J.; Wang, W.; et al. Downregulation of blood serum microRNA 29 family in patients with Parkinson's disease. Sci. Rep. 2017, 7, 5411. [CrossRef]

39. Khoo, S.K.; Petillo, D.; Kang, U.J.; Resau, J.H.; Berryhill, B.; Linder, J.; Forsgren, L.; Neuman, L.A.; Tan, A.C. Plasma-based circulating MicroRNA biomarkers for Parkinson's disease. J. Parkinsons Dis. 2012, 2, 321-331. [CrossRef]

40. Cardo, L.F.; Coto, E.; De Mena, L.; Ribacoba, R.; Morís, G.; Menéndez, M.; Alvarez, V. Profile of microRNAs in the plasma of Parkinson's disease patients and healthy controls. J. Neurol. 2013, 260, 1420-1422. [CrossRef]

41. Li, N.; Pan, X.; Zhang, J.; Ma, A.-J.; Xie, A.; Yang, S. Plasma levels of miR-137 and miR-124 are associated with Parkinson's disease but not with Parkinson's disease with depression. Neurol. Sci. 2017, 38, 761-767. [CrossRef] [PubMed]

42. Schwienbacher, C.; Foco, L.; Picard, A.; Corradi, E.; Serafin, A.; Panzer, J.; Zanigni, S.; Blankenburg, H.; Facheris, M.F.; Giannini, G.; et al. Plasma and White Blood Cells Show Different miRNA Expression Profiles in Parkinson's Disease. J. Mol. Neurosci. 2017, 62, 244-254. [CrossRef] [PubMed] 
43. Yang, Z.; Li, T.; Cui, Y.; Li, S.; Cheng, C.; Shen, B.; Le, W. Elevated Plasma microRNA-105-5p Level in Patients with Idiopathic Parkinson's Disease: A Potential Disease Biomarker. Front. Mol. Neurosci. 2019, 13, 218. [CrossRef] [PubMed]

44. Zhang, X.; Yang, R.; Hu, B.-L.; Lu, P.; Zhou, L.-L.; He, Z.-Y.; Wu, H.-M.; Zhu, J.-H. Reduced Circulating Levels of miR-433 and miR-133b Are Potential Biomarkers for Parkinson's Disease. Front. Cell. Neurosci. 2017, 11, 170. [CrossRef]

45. Chen, L.; Yang, J.; Lü, J.; Cao, S.; Zhao, Q.; Yu, Z. Identification of aberrant circulating miRNAs in Parkinson's disease plasma samples. Brain Behav. 2018, 8, e00941. [CrossRef]

46. Yao, Y.F.; Qu, M.W.; Li, G.C.; Zhang, F.B.; Rui, H.C. Circulating exosomal miRNAs as diagnostic biomarkers in Parkinson's disease. Eur. Rev. Med. Pharmacol. Sci. 2018, 22, 5278-5283.

47. Yang, Z.; Li, T.; Li, S.; Wei, M.; Qi, H.; Shen, B.; Chang, R.C.-C.; Le, W.; Piao, F. Altered Expression Levels of MicroRNA-132 and Nurr1 in Peripheral Blood of Parkinson's Disease: Potential Disease Biomarkers. ACS Chem. Neurosci. 2019, 10, 2243-2249. [CrossRef]

48. Ravanidis, S.; Bougea, A.; Papagiannakis, N.; Maniati, M.; Koros, C.; Simitsi, A.M.; Bozi, M.; Pachi, I.; Stamelou, M.; Paraskevas, G.P.; et al. Circulating Brain-enriched MicroRNAs for detection and discrimination of idiopathic and genetic Parkinson's disease. Mov. Disord. 2020, 35, 457-467. [CrossRef]

49. Pasinetti, G.M. Role of Personalized Medicine in the Identification and Characterization of Parkinson's Disease in Asymptomatic Subjects. J. Alzheimers Dis. Parkinsonism 2012, 2. [CrossRef]

50. Serafin, A.; Foco, L.; Zanigni, S.; Blankenburg, H.; Picard, A.; Zanon, A.; Giannini, G.; Pichler, I.; Facheris, M.F.; Cortelli, P.; et al. Overexpression of blood microRNAs 103a, 30b, and 29a in L-dopa-treated patients with PD. Neurology 2015, 84, 645-653. [CrossRef]

51. Caggiu, E.; Paulus, K.; Mameli, G.; Arru, G.; Sechi, G.P.; Sechi, L.A. Differential expression of miRNA 155 and miRNA 146a in Parkinson's disease patients. eNeurologicalSci 2018, 13, 1-4. [CrossRef] [PubMed]

52. Martins, M.; Rosa, A.; Guedes, L.C.; Fonseca, B.V.; Gotovac, K.; Violante, S.; Mestre, T.; Coelho, M.; Rosa, M.M.; Martin, E.R.; et al. Convergence of miRNA expression profiling, alpha-synuclein interacton and GWAS in Parkinson's disease. PLoS ONE 2011, 6, e25443. [CrossRef] [PubMed]

53. Behbahanipour, M.; Peymani, M.; Salari, M.; Hashemi, M.S.; Nasr-Esfahani, M.H.; Ghaedi, K. Expression Profiling of Blood microRNAs 885, 361, and 17 in the Patients with the Parkinson's disease: Integrating Interaction Data to Uncover the Possible Triggering Age-Related Mechanisms. Sci Rep. 2019, 9, 13759. [CrossRef] [PubMed]

54. Baghi, M.; Rostamian Delavar, M.; Yadegari, E.; Peymani, M.; Pozo, D.; Hossein Nasr-Esfahani, M.; Ghaedi, K. Modified level of miR-376a is associated with Parkinson's disease. J. Cell. Mol. Med. 2020, 24, 2622-2634. [CrossRef] [PubMed]

55. Alieva, A.K.; Filatova, E.V.; Karabanov, A.V.; Illarioshkin, S.N.; Limborska, S.A.; Shadrina, M.I.; Slominsky, P.A. miRNA expression is highly sensitive to a drug therapy in Parkinson's disease. Park. Relat. Disord. 2015, 21, 72-74. [CrossRef] [PubMed]

56. Cressatti, M.; Juwara, L.; Galindez, J.M.; Velly, A.M.; Nkurunziza, E.S.; Marier, S.; Canie, O.; Gornistky, M.; Schipper, H.M. Salivary microR-153 and microR-223 Levels as Potential Diagnostic Biomarkers of Idiopathic Parkinson's Disease. Mov. Disord. 2019, 35, 468-477. [CrossRef] [PubMed]

57. Chen, Y.; Zheng, J.; Su, L.; Chen, F.; Zhu, R.; Chen, X.; Ye, Q. Increased Salivary microRNAs That Regulate DJ-1 Gene Expression as Potential Markers for Parkinson's Disease. Front. Aging Neurosci. 2020, 12, 210. [CrossRef]

58. Burgos, K.; Malenica, I.; Metpally, R.; Courtright, A.; Rakela, B.; Beach, T.; Shill, H.; Adler, C.; Sabbagh, M.; Villa, S.; et al. Profiles of extracellular miRNA in cerebrospinal fluid and serum from patients with Alzheimer's and Parkinson's diseases correlate with disease status and features of pathology. PLoS ONE 2014, 9, e94839. [CrossRef]

59. Devaux, Y.; Dankiewicz, J.; Salgado-Somoza, A.; Stammet, P.; Collignon, O.; Gilje, P.; Gidlof, O.; Zhang, L.; Vausort, M.; Hassager, C.; et al. Association of Circulating MicroRNA-124-3p Levels with Outcomes after out-of-Hospital Cardiac Arrest: A Substudy of a Randomized Clinical Trial. JAMA Cardiol. 2016, 1, 305-313. [CrossRef]

60. Devaux, Y.; Salgado-Somoza, A.; Dankiewicz, J.; Boileau, A.; Stammet, P.; Schritz, A.; Zhang, L.; Vausort, M.; Gilje, P.; Erlinge, D.; et al. Incremental Value of Circulating MiR-122-5p to Predict Outcome after out of Hospital Cardiac Arrest. Theranostics 2017, 7, 2555-2564. [CrossRef] 
61. Braza-Boïls, A.; Barwari, T.; Gutmann, C.; Thomas, M.R.; Judge, H.M.; Joshi, A.; Pechlaner, R.; Shankar-Hari, M.; Ajjan, R.A.; Sabroe, I.; et al. Circulating MicroRNA Levels Indicate Platelet and Leukocyte Activation in Endotoxemia Despite Platelet P2Y12 Inhibition. Int. J. Mol. Sci. 2020, $21,2897$. [CrossRef] [PubMed]

62. Devaux, Y. Transcriptome of blood cells as a reservoir of cardiovascular biomarkers. Biochim. Biophys. Acta (BBA) Bioenerg. 2017, 1864, 209-216. [CrossRef] [PubMed]

63. Kern, F.; Fehlmann, T.; Violich, I.; Alsop, E.; Hutchins, E.D.; Kahraman, M.; Grammes, N.; Guimaraes, P.; Backes, C.; Poston, K.L.; et al. Deep sncRNA-seq of the PPMI cohort to study Parkinson's disease progression. BioRxiv 2020. [CrossRef]

64. Briggs, C.E.; Wang, Y.; Kong, B.; Woo, T.-U.W.; Iyer, L.K.; Sonntag, K.C. Midbrain dopamine neurons in Parkinson's disease exhibit a dysregulated miRNA and target-gene network. Brain Res. 2015, 1618, 111-121. [CrossRef]

65. Li, D.; Yang, H.; Ma, J.; Luo, S.; Chen, S.; Gu, Q. MicroRNA-30e regulates neuroinflammation in MPTP model of Parkinson's disease by targeting Nlrp3. Hum. Cell 2017, 31, 106-115. [CrossRef]

66. Li, L.; Liu, H.; Song, H.; Qin, Y.; Wang, Y.; Xu, M.; Liu, C.; Gao, J.; Sun, S. Let-7d microRNA Attenuates 6-OHDA-Induced Injury by Targeting Caspase-3 in MN9D Cells. J. Mol. Neurosci. 2017, 63, $403-411$. [CrossRef]

67. Chen, Y.; Gao, C.; Sun, Q.; Pan, H.; Huang, P.; Ding, J.; Chen, S. MicroRNA-4639 Is a Regulator of DJ-1 Expression and a Potential Early Diagnostic Marker for Parkinson's Disease. Front. Aging Neurosci. 2017, 9, 232. [CrossRef]

68. Choi, D.C.; Yoo, M.; Kabaria, S.; Junn, E. MicroRNA-7 facilitates the degradation of alpha-synuclein and its aggregates by promoting autophagy. Neurosci. Lett. 2018, 678, 118-123. [CrossRef]

69. Cao, B.; Wang, T.; Qu, Q.; Kang, T.; Yang, Q. Long Noncoding RNA SNHG1 Promotes Neuroinflammation in Parkinson's Disease via Regulating miR-7/NLRP3 Pathway. Neuroscience 2018, 388, 118-127. [CrossRef]

70. Je, G.; Kim, Y.-S. Mitochondrial ROS-mediated post-transcriptional regulation of $\alpha$-synuclein through miR-7 and miR-153. Neurosci. Lett. 2017, 661, 132-136. [CrossRef]

71. Wang, Z.-H.; Zhang, J.-L.; Duan, Y.-L.; Zhang, Q.-S.; Li, G.-F.; Zheng, D.-L. MicroRNA-214 participates in the neuroprotective effect of Resveratrol via inhibiting $\alpha$-synuclein expression in MPTP-induced Parkinson's disease mouse. Biomed. Pharmacother. 2015, 74, 252-256. [CrossRef] [PubMed]

72. Cho, H.J.; Liu, G.; Jin, S.M.; Parisiadou, L.; Xie, C.; Yu, J.; Sun, L.; Ma, B.; Ding, J.; Vancraenenbroeck, R.; et al. MicroRNA-205 regulates the expression of Parkinson's disease-related leucine-rich repeat kinase 2 protein. Hum. Mol. Genet. 2013, 22, 608-620. [CrossRef] [PubMed]

73. Li, W.; Jiang, Y.; Wang, Y.; Yang, S.; Bi, X.; Pan, X.; Ma, A.-J. MiR-181b regulates autophagy in a model of Parkinson's disease by targeting the PTEN/Akt/mTOR signaling pathway. Neurosci. Lett. 2018, 675, 83-88. [CrossRef] [PubMed]

74. Yao, L.; Ye, Y.; Mao, H.; Lu, F.; He, X.; Lu, G.; Zhang, S. MicroRNA-124 regulates the expression of MEKK3 in the inflammatory pathogenesis of Parkinson's disease. J. Neuroinflam. 2018, 15, 13. [CrossRef] [PubMed]

75. Horst, C.H.; Titze-De-Almeida, R.; De Almeida, S.S.T. The involvement of Eag1 potassium channels and miR-34a in rotenone-induced death of dopaminergic SH-SY5Y cells. Mol. Med. Rep. 2017, 15, 1479-1488. [CrossRef]

76. Ren, Y.; Li, H.; Xie, W.; Wei, N.; Liu, M. MicroRNA195 triggers neuroinflammation in Parkinson's disease in a Rhoassociated kinase 1dependent manner. Mol. Med. Rep. 2019, 19, 5153-5161. [CrossRef]

77. Ding, X.-M.; Zhao, L.-J.; Qiao, H.-Y.; Wu, S.-L.; Wang, X.-H. Long non-coding RNA-p21 regulates MPP+-induced neuronal injury by targeting miR-625 and derepressing TRPM2 in SH-SY5Y cells. Chem. Interact. 2019, 307, 73-81. [CrossRef]

78. Ye, Y.; He, X.; Lu, F.; Mao, H.; Zhu, Z.; Yao, L.; Luo, W.; Sun, X.; Wang, B.; Qian, C.; et al. A lincRNA-p21/miR-181 family feedback loop regulates microglial activation during systemic LPS- and MPTP- induced neuroinflammation. Cell Death Dis. 2018, 9, 803. [CrossRef]

79. Thome, A.D.; Harms, A.S.; Volpicelli-Daley, L.A.; Standaert, D.G. microRNA-155 Regulates Alpha-Synuclein-Induced Inflammatory Responses in Models of Parkinson Disease. J. Neurosci. 2016, 36, 2383-2390. [CrossRef]

80. Zhang, L.-M.; Wang, M.-H.; Yang, H.-C.; Tian, T.; Sun, G.-F.; Ji, Y.-F.; Hu, W.-T.; Liu, X.; Wang, J.-P.; Lu, H. Dopaminergic neuron injury in Parkinson's disease is mitigated by interfering lncRNA SNHG14 expression to regulate the miR-133b/ $\alpha$-synuclein pathway. Aging 2019, 11, 9264-9279. [CrossRef] 
81. Zhang, J.; Liu, W.; Wang, Y.; Zhao, S.; Chang, N. miR-135b Plays a Neuroprotective Role by Targeting GSK3beta in MPP(+)-Intoxicated SH-SY5Y Cells. Dis. Markers 2017, 2017, 5806146. [CrossRef] [PubMed]

82. Minones-Moyano, E.; Porta, S.; Escaramis, G.; Rabionet, R.; Iraola, S.; Kagerbauer, B.; Espinosa-Parrilla, Y.; Ferrer, I.; Estivill, X.; Marti, E. MicroRNA profiling of Parkinson's disease brains identifies early downregulation of miR-34b/c which modulate mitochondrial function. Hum. Mol. Genet. 2011, 20, 3067-3078. [CrossRef] [PubMed]

83. Wang, J.; Le, T.; Wei, R.; Jiao, Y. Knockdown of JMJD1C, a target gene of hsa-miR-590-3p, inhibits mitochondrial dysfunction and oxidative stress in MPP+-treated MES23.5 and SH-SY5Y cells. Cell. Mol. Biol. 2016, 62, $39-45$.

84. Chaudhuri, A.D.; Choi, D.C.; Kabaria, S.; Tran, A.; Junn, E. MicroRNA-7 Regulates the Function of Mitochondrial Permeability Transition Pore by Targeting VDAC1 Expression. J. Biol. Chem. 2016, 291, 6483-6493. [CrossRef] [PubMed]

85. Kabaria, S.; Choi, D.C.; Chaudhuri, A.D.; Mouradian, M.M.; Junn, E. Inhibition of miR-34b and miR-34c enhances $\alpha$-synuclein expression in Parkinson's disease. FEBS Lett. 2014, 589, 319-325. [CrossRef]

86. Chen, Y.; Lian, Y.-J.; Ma, Y.-Q.; Wu, C.-J.; Zheng, Y.-K.; Xie, N.-C. LncRNA SNHG1 promotes $\alpha$-synuclein aggregation and toxicity by targeting miR-15b-5p to activate SIAH1 in human neuroblastoma SH-SY5Y cells. NeuroToxicology 2018, 68, 212-221. [CrossRef]

87. Wang, Y.; Cai, Y.; Huang, H.; Chen, X.; Chen, X.; Chen, X.; Mai, H.; Li, X.; Zhao, J.; Yang, J.; et al. miR-486-3p Influences the Neurotoxicity of a-Synuclein by Targeting the SIRT2 Gene and the Polymorphisms at Target Sites Contributing to Parkinson's Disease. Cell. Physiol. Biochem. 2018, 51, 2732-2745. [CrossRef]

88. Liang, H.; Ding, B.; Liang, J.; Shi, X.; Jiang, X.; Gao, Y. MicroRNA-10a inhibits A30P $\alpha$-synuclein aggregation and toxicity by targeting proapoptotic protein BCL2L11. Int. J. Clin. Exp. Pathol. 2018, 11, 624-633.

89. Li, G.; Yang, H.; Zhu, D.; Huang, H.; Liu, G.; Lun, P. Targeted Suppression of Chaperone-Mediated Autophagy by miR-320a Promotes $\alpha$-Synuclein Aggregation. Int. J. Mol. Sci. 2014, 15, 15845-15857. [CrossRef]

90. Zhang, Z.; Cheng, Y. miR-16-1 Promotes the Aberrant $\alpha$-Synuclein Accumulation in Parkinson Disease via Targeting Heat Shock Protein 70. Sci. World J. 2014, 2014, 938348. [CrossRef]

91. Peng, T.; Liu, X.; Wang, J.; Liu, Y.; Fu, Z.; Ma, X.; Li, J.; Sun, G.; Ji, Y.; Lu, J.; et al. Long noncoding RNA HAGLROS regulates apoptosis and autophagy in Parkinson's disease via regulating miR-100/ATG10 axis and PI3K/Akt/mTOR pathway activation. Artif. Cells Nanomed. Biotechnol. 2019, 47, 2764-2774. [CrossRef]

92. Wen, Z.; Zhang, J.; Tang, P.; Tu, N.; Wang, K.; Wu, G. Overexpression of miR185 inhibits autophagy and apoptosis of dopaminergic neurons by regulating the AMPK/mTOR signaling pathway in Parkinson's disease. Mol. Med. Rep. 2018, 17, 131-137. [CrossRef] [PubMed]

93. Zhao, X.H.; Wang, Y.B.; Yang, J.; Liu, H.Q.; Wang, L.L. MicroRNA-326 suppresses iNOS expression and promotes autophagy of dopaminergic neurons through the JNK signaling by targeting XBP1 in a mouse model of Parkinson's disease. J. Cell. Biochem. 2019, 120, 14995-15006. [CrossRef] [PubMed]

94. Kim, J.; Fiesel, F.C.; Belmonte, K.C.; Hudec, R.; Wang, W.-X.; Kim, C.; Nelson, P.T.; Springer, W.; Kim, J. $\mathrm{miR}-27 \mathrm{a}$ and $\mathrm{miR}-27 \mathrm{~b}$ regulate autophagic clearance of damaged mitochondria by targeting PTEN-induced putative kinase 1 (PINK1). Mol. Neurodegener. 2016, 11, 55. [CrossRef]

95. Zhou, T.; Lin, D.; Chen, Y.; Peng, S.; Jing, X.; Lei, M.; Enxiang, T.; Liang, Y. $\alpha$-synuclein accumulation in SH-SY5Y cell impairs autophagy in microglia by exosomes overloading miR-19a-3p. Epigenomics 2019, 11, 1661-1677. [CrossRef] [PubMed]

96. Liu, Y.; Song, Y.; Zhu, X. MicroRNA-181a Regulates Apoptosis and Autophagy Process in Parkinson's Disease by Inhibiting p38 Mitogen-Activated Protein Kinase (MAPK)/c-Jun N-Terminal Kinases (JNK) Signaling Pathways. Med. Sci. Monit. 2017, 23, 1597-1606. [CrossRef] [PubMed]

97. Kumar, L.; Nazir, A. Modulation of Alpha-synuclein Expression and Associated Effects by MicroRNA Let-7 in Transgenic C. elegans. Front. Mol. Neurosci. 2017, 10, 328. [CrossRef]

98. Jauhari, A.; Singh, T.; Mishra, S.; Shankar, J.; Yadav, S. Coordinated Action of miR-146a and Parkin Gene Regulate Rotenone-induced Neurodegeneration. Toxicol. Sci. 2020, 176, 433-445. [CrossRef]

99. Chiu, C.-C.; Yeh, T.-H.; Chen, R.-S.; Chen, H.-C.; Huang, Y.-Z.; Weng, Y.-H.; Cheng, Y.-C.; Liu, Y.-C.; Cheng, A.-J.; Lu, Y.-C.; et al. Upregulated Expression of MicroRNA-204-5p Leads to the Death of Dopaminergic Cells by Targeting DYRK1A-Mediated Apoptotic Signaling Cascade. Front. Cell. Neurosci. 2019, 13, 399. [CrossRef] 
100. Xu, L.; Jia, Y.; Yang, X.-H.; Han, F.; Zheng, Y.; Ni, Y.; Chen, X.; Hong, J.; Liu, J.-Q.; Li, Q.; et al. MicroRNA-130b transcriptionally regulated by histone $\mathrm{H} 3$ deacetylation renders Akt ubiquitination and apoptosis resistance to 6-OHDA. Biochim. Biophys. Acta (BBA) Mol. Basis Dis. 2017, 1863, 1678-1689. [CrossRef]

101. Tao, H.; Liu, Y.; Hou, Y. miRNA3845p regulates the progression of Parkinson's disease by targeting SIRT1 in mice and SHSY5Y cell. Int. J. Mol. Med. 2020, 45, 441-450. [PubMed]

102. Bauer, M.; Kinkl, N.; Meixner, A.; Kremmer, E.; Riemenschneider, M.; Forstl, H.; Gasser, T.; Ueffing, M. Prevention of interferon-stimulated gene expression using microRNA-designed hairpins. Gene. Ther. 2009, 16, 142-147. [CrossRef] [PubMed]

103. Sibley, C.R.; Seow, Y.; Curtis, H.J.; Weinberg, M.S.; Wood, M. Silencing of Parkinson's disease-associated genes with artificial mirtron mimics of miR-1224. Nucleic Acids Res. 2012, 40, 9863-9875. [CrossRef] [PubMed]

104. Han, Y.; Khodr, C.E.; Sapru, M.K.; Pedapati, J.; Bohn, M.C. A microRNA embedded AAV alpha-synuclein gene silencing vector for dopaminergic neurons. Brain Res. 2011, 1386, 15-24. [CrossRef] [PubMed]

105. Poole, E.; Kuan, W.L.; Barker, R.; Sinclair, J. The human cytomegalovirus non-coding Beta2.7 RNA as a novel therapeutic for Parkinson's disease-Translational research with no translation. Virus Res. 2016, 212, 64-69. [CrossRef] [PubMed]

106. Saraiva, C.; Paiva, J.; Santos, T.; Ferreira, L.; Bernardino, L. MicroRNA-124 loaded nanoparticles enhance brain repair in Parkinson's disease. J. Control. Release 2016, 235, 291-305. [CrossRef]

107. Dong, R.F.; Zhang, B.; Tai, L.W.; Liu, H.M.; Shi, F.K.; Liu, N.N. The Neuroprotective Role of MiR-124-3p in a 6-Hydroxydopamine-Induced Cell Model of Parkinson's Disease via the Regulation of ANAX5. J. Cell. Biochem. 2018, 119, 269-277. [CrossRef]

108. Andersen, R.E.; Lim, D.A. Forging our understanding of lncRNAs in the brain. Cell Tissue Res. 2017, 371, 55-71. [CrossRef]

109. Shi, C.; Zhang, L.; Qin, C. Long non-coding RNAs in brain development, synaptic biology, and Alzheimer's disease. Brain Res. Bull. 2017, 132, 160-169. [CrossRef]

110. Majidinia, M.; Mihanfar, A.; Rahbarghazi, R.; Nourazarian, A.; Bagca, B.; Avci, C.B. The roles of non-coding RNAs in Parkinson's disease. Mol. Biol. Rep. 2016, 43, 1193-1204. [CrossRef]

111. Salta, E.; De Strooper, B. Noncoding RNAs in neurodegeneration. Nat. Rev. Neurosci. 2017, 18, 627-640. [CrossRef]

112. Devaux, Y.; Creemers, E.E.; Boon, R.A.; Werfel, S.; Thum, T.; Engelhardt, S.; Dimmeler, S.; Squire, I.; Network, O.B.O.T.C. Circular RNAs in heart failure. Eur. J. Hear. Fail. 2017, 19, 701-709. [CrossRef] [PubMed]

113. Gomes, C.P.D.C.; Schroen, B.; Kuster, G.M.; Robinson, E.L.; Ford, K.; Squire, I.B.; Heymans, S.; Martelli, F.; Emanueli, C.; Devaux, Y.; et al. Regulatory RNAs in Heart Failure. Circulation 2020, 141, 313-328. [CrossRef]

114. Mortezaei, Z.; Lanjanian, H.; Masoudi-Nejad, A. Candidate novel long noncoding RNAs, MicroRNAs and putative drugs for Parkinson's disease using a robust and efficient genome-wide association study. Genomics 2017, 109, 158-164. [CrossRef]

115. Kraus, T.F.J.; Haider, M.; Spanner, J.; Steinmaurer, M.; Dietinger, V.; Kretzschmar, H.A. Altered Long Noncoding RNA Expression Precedes the Course of Parkinson's Disease-A Preliminary Report. Mol. Neurobiol. 2016, 54, 2869-2877. [CrossRef] [PubMed]

116. Simchovitz, A.; Hanan, M.; Niederhoffer, N.; Madrer, N.; Yayon, N.; Bennett, E.R.; Greenberg, D.S.; Kadener, S.; Soreq, H. NEAT1 is overexpressed in Parkinson's disease substantia nigra and confers drug-inducible neuroprotection from oxidative stress. FASEB J. 2019, 33, 11223-11234. [CrossRef] [PubMed]

117. Boros, F.A.; Maszlag-Török, R.; Vécsei, L.; Klivényi, P. Increased level of NEAT1 long non-coding RNA is detectable in peripheral blood cells of patients with Parkinson's disease. Brain Res. 2020, 1730, 146672. [CrossRef] [PubMed]

118. Ni, Y.; Huang, H.; Chen, Y.; Cao, M.; Zhou, H.; Zhang, Y. Investigation of Long Non-coding RNA Expression Profiles in the Substantia Nigra of Parkinson's Disease. Cell. Mol. Neurobiol. 2016, 37, 329-338. [CrossRef] [PubMed]

119. Soreq, L.; Guffanti, A.; Salomonis, N.; Simchovitz, A.; Israel, Z.; Bergman, H.; Soreq, H. Long non-coding RNA and alternative splicing modulations in Parkinson's leukocytes identified by RNA sequencing. PLoS Comput. Biol. 2014, 10, e1003517. [CrossRef] 
120. Fan, Y.; Li, J.; Yang, Q.; Gong, C.; Gao, H.; Mao, Z.; Yuan, X.; Zhu, S.; Xue, Z. Dysregulated Long Non-coding RNAs in Parkinson's Disease Contribute to the Apoptosis of Human Neuroblastoma Cells. Front. Mol. Neurosci. 2019, 13, 1320. [CrossRef]

121. Fan, Y.; Xue, Z. Plasma-based circulating long non-coding RNA AS-Uch1 as a novel diagnostic biomarker for Parkinson's disease. In Proceedings of the 2019 International Congress, Nice, France, 22-26 September 2019.

122. Zhao, J.; Geng, L.; Chen, Y.; Wu, C. SNHG1 promotes MPP+-induced cytotoxicity by regulating PTEN/AKT/mTOR signaling pathway in SH-SY5Y cells via sponging miR-153-3p. Biol. Res. 2020, 53, 1. [CrossRef] [PubMed]

123. Zhang, L.; Wang, J.; Liu, Q.; Xiao, Z.; Dai, Q. Knockdown of long non-coding RNA AL049437 mitigates MPP+ -induced neuronal injury in SH-SY5Y cells via the microRNA-205-5p/MAPK1 axis. NeuroToxicology 2020, 78, 29-35. [CrossRef]

124. Liu, S.; Cui, B.; Dai, Z.-X.; Shi, P.-K.; Wang, Z.-H.; Guo, Y.-Y. Long Non-coding RNA HOTAIR Promotes Parkinson's Disease Induced by MPTP through up-regulating the Expression of LRRK2. Curr. Neurovascular Res. 2016, 13, 115-120. [CrossRef] [PubMed]

125. Coupland, K.; Kim, W.S.; Halliday, G.M.; Hallupp, M.; Dobson-Stone, C.; Kwok, J.B. Role of the Long Non-Coding RNA MAPT-AS1 in Regulation of Microtubule Associated Protein Tau (MAPT) Expression in Parkinson's Disease. PLoS ONE 2016, 11, e0157924. [CrossRef] [PubMed]

126. Lin, D.; Liang, Y.; Jing, X.; Chen, Y.; Lei, M.; Zeng, Z.; Zhou, T.; Wu, X.; Peng, S.; Zheng, D.; et al. Microarray analysis of an synthetic $\alpha$-synuclein induced cellular model reveals the expression profile of long non-coding RNA in Parkinson's disease. Brain Res. 2018, 1678, 384-396. [CrossRef] [PubMed]

127. Xie, S.-P.; Zhou, F.; Li, J.; Duan, S.-J. NEAT1 regulates MPP+-induced neuronal injury by targeting miR-124 in neuroblastoma cells. Neurosci. Lett. 2019, 708, 134340. [CrossRef]

128. Yan, W.; Chen, Z.Y.; Chen, J.Q.; Chen, H.M. LncRNA NEAT1 promotes autophagy in MPTP-induced Parkinson's disease through stabilizing PINK1 protein. Biochem. Biophys. Res. Commun. 2018, 496, 1019-1024. [CrossRef]

129. Liu, W.; Zhang, Q.; Zhang, J.; Pan, W.; Zhao, J.; Xu, Y. Long non-coding RNA MALAT1 contributes to cell apoptosis by sponging miR-124 in Parkinson disease. Cell Biosci. 2017, 7, 19. [CrossRef]

130. Lu, Y.; Gong, Z.; Jin, X.; Zhao, P.; Zhang, Y.; Wang, Z. LncRNA MALAT1 targeting miR-124-3p regulates DAPK1 expression contributes to cell apoptosis in Parkinson's Disease. J. Cell. Biochem. 2020. [CrossRef]

131. Li, Y.; Fang, J.; Zhou, Z.; Zhou, Q.; Sun, S.; Jin, Z.; Xi, Z.; Wei, J. Downregulation of lncRNA BACE1-AS improves dopamine-dependent oxidative stress in rats with Parkinson's disease by upregulating microRNA-34b-5p and downregulating BACE1. Cell Cycle 2020, 19, 1158-1171. [CrossRef]

132. Carrieri, C.; Forrest, A.R.; Santoro, C.; Persichetti, F.; Carninci, P.; Zucchelli, S.; Gustincich, S. Expression analysis of the long non-coding RNA antisense to Uchl1 (AS Uchl1) during dopaminergic cells' differentiation in vitro and in neurochemical models of Parkinson's disease. Front. Cell. Neurosci. 2015, 9, 114. [CrossRef] [PubMed]

133. Jiang, J.; Piao, X.; Hu, S.; Gao, J.; Bao, M. LncRNA H19 diminishes dopaminergic neuron loss by mediating microRNA-301b-3p in Parkinson's disease via the HPRT1-mediated Wnt/beta-catenin signaling pathway. Aging (Albany NY) 2020, 12, 8820-8836. [CrossRef] [PubMed]

134. Zhang, Y.; Xia, Q.; Lin, J. LncRNA H19 Attenuates Apoptosis in MPTP-Induced Parkinson's Disease through Regulating miR-585-3p/PIK3R3. Neurochem. Res. 2020, 45, 1700-1710. [CrossRef] [PubMed]

135. Lin, Q.; Hou, S.; Dai, Y.; Jiang, N.; Lin, Y. LncRNA HOTAIR targets miR-126-5p to promote the progression of Parkinson's disease through RAB3IP. Biol. Chem. 2019, 400, 1217-1228. [CrossRef]

136. Cai, L.; Tu, L.; Li, T.; Yang, X.; Ren, Y.; Gu, R.; Zhang, Q.; Yao, H.; Qu, X.; Wang, Q.; et al. Downregulation of lncRNA UCA1 ameliorates the damage of dopaminergic neurons, reduces oxidative stress and inflammation in Parkinson's disease through the inhibition of the PI3K/Akt signaling pathway. Int. Immunopharmacol. 2019, 75, 105734. [CrossRef]

137. Yang, H.; Lin, Q.; Chen, N.; Luo, Z.; Zheng, C.; Li, J.; Zheng, F.; Guo, Z.; Cai, P.; Wu, S.; et al. LncRNA NR_030777 Alleviates Paraquat-induced Neurotoxicity by Regulating Zfp326 and Cpne5. Toxicol. Sci. 2020. [CrossRef]

138. Simchovitz, A.; Hanan, M.; Yayon, N.; Lee, S.; Bennett, E.R.; Greenberg, D.S.; Kadener, S.; Soreq, H. A lncRNA survey finds increases in neuroprotective LINC-PINT in Parkinson's disease substantia nigra. Aging Cell 2020, 19, e13115. [CrossRef] 
139. Lu, M.; Sun, W.-L.; Shen, J.; Wei, M.; Chen, B.; Qi, Y.-J.; Xu, C.-S. LncRNA-UCA1 promotes PD development by upregulating SNCA. Eur. Rev. Med. Pharmacol. Sci. 2018, 22, 7908-7915.

140. Qian, C.; Ye, Y.; Mao, H.; Yao, L.; Sun, X.; Wang, B.; Zhang, H.; Xie, L.; Zhang, H.; Zhang, Y.; et al. Downregulated lncRNA-SNHG1 enhances autophagy and prevents cell death through the miR-221/222 /p27/mTOR pathway in Parkinson's disease. Exp. Cell Res. 2019, 384, 111614. [CrossRef]

141. Xu, W.; Zhang, L.; Geng, Y.; Liu, Y.; Zhang, N. Long noncoding RNA GAS5 promotes microglial inflammatory response in Parkinson's disease by regulating NLRP3 pathway through sponging miR-223-3p. Int. Immunopharmacol. 2020, 85, 106614. [CrossRef]

142. Liu, R.; Li, F.; Zhao, W. Long noncoding RNA NEAT1 knockdown inhibits MPP(+)-induced apoptosis, in $\mathrm{fl}$ ammation and cytotoxicity in SK-N-SH cells by regulating miR-212-5p/RAB3IP axis. Neurosci. Lett. 2020, 731, 135060. [CrossRef] [PubMed]

143. Song, Q.; Geng, Y.; Li, Y.; Wang, L.; Qin, J. Long noncoding RNA NORAD regulates MPP+-induced Parkinson's disease model cells. J. Chem. Neuroanat. 2019, 101, 101668. [CrossRef] [PubMed]

144. D'Ambra, E.; Capauto, D.; Morlando, M. Exploring the Regulatory Role of Circular RNAs in Neurodegenerative Disorders. Int. J. Mol. Sci. 2019, 20, 5477. [CrossRef] [PubMed]

145. Lukiw, W.J. Circular RNA (circRNA) in Alzheimer's disease (AD). Front. Genet. 2013, 4, 307. [CrossRef] [PubMed]

146. Choi, D.C.; Chae, Y.-J.; Kabaria, S.; Chaudhuri, A.D.; Jain, M.R.; Li, H.; Mouradian, M.M.; Junn, E. MicroRNA-7 protects against 1-methyl-4-phenylpyridinium-induced cell death by targeting RelA. J. Neurosci. 2014, 34, 12725-12737. [CrossRef] [PubMed]

147. Sang, Q.; Liu, X.; Wang, L.; Qi, L.; Sun, W.; Wang, W.; Sun, Y.; Zhang, H. CircSNCA downregulation by pramipexole treatment mediates cell apoptosis and autophagy in Parkinson's disease by targeting miR-7. Aging 2018, 10, 1281-1293. [CrossRef]

148. Feng, Z.; Zhang, L.; Wang, S.; Hong, Q. Circular RNA circDLGAP4 exerts neuroprotective effects via modulating miR-134-5p/CREB pathway in Parkinson's disease. Biochem. Biophys. Res. Commun. 2020, 522, 388-394. [CrossRef]

149. Kumar, L.; Jadiya, P.; Haque, R.; Shukla, S.; Nazir, A. Functional Characterization of Novel Circular RNA Molecule, circzip-2 and Its Synthesizing Gene zip-2 in C. elegans Model of Parkinson's Disease. Mol. Neurobiol. 2018, 55, 6914-6926. [CrossRef]

150. Jia, E.; Zhou, Y.; Liu, Z.; Wang, L.; Ouyang, T.; Pan, M.; Bai, Y.; Ge, Q. Transcriptomic Profiling of Circular RNA in Different Brain Regions of Parkinson's Disease in a Mouse Model. Int. J. Mol. Sci. 2020, 21, 3006. [CrossRef]

151. Hanan, M.; Simchovitz, A.; Yayon, N.; Vaknine, S.; Cohen-Fultheim, R.; Karmon, M.; Madrer, N.; Rohrlich, T.M.; Maman, M.; Bennett, E.R.; et al. A Parkinson's disease Circ RNA s Resource reveals a link between circ SLC 8A1 and oxidative stress. EMBO Mol. Med. 2020, 11942. [CrossRef]

152. Pekarsky, Y.; Balatti, V.; Palamarchuk, A.; Rizzotto, L.; Veneziano, D.; Nigita, G.; Rassenti, L.Z.; Pass, H.; Kipps, T.J.; Liu, C.-G.; et al. Dysregulation of a family of short noncoding RNAs, tsRNAs, in human cancer. Proc. Natl. Acad. Sci. USA 2016, 113, 5071-5076. [CrossRef] [PubMed]

153. Balatti, V.; Nigita, G.; Veneziano, D.; Drusco, A.; Stein, G.S.; Messier, T.L.; Farina, N.H.; Lian, J.B.; Tomasello, L.; Liu, C.-G.; et al. tsRNA signatures in cancer. Proc. Natl. Acad. Sci. USA 2017, 114, 8071-8076. [CrossRef] [PubMed]

154. Blanco, S.; Dietmann, S.; Flores, J.V.; Hussain, S.; Kutter, C.; Humphreys, P.; Lukk, M.; Lombard, P.; Treps, L.; Popis, M.; et al. Aberrant methylation of $\mathrm{t}$ RNA s links cellular stress to neuro-developmental disorders. EMBO J. 2014, 33, 2020-2039. [CrossRef]

155. Van Es, M.A.; Schelhaas, H.J.; Van Vught, P.W.J.; Ticozzi, N.; Andersen, P.M.; Groen, E.J.N.; Schulte, C.; Blauw, H.M.; Koppers, M.; Diekstra, F.P.; et al. Angiogenin variants in Parkinson disease and amyotrophic lateral sclerosis. Ann. Neurol. 2011, 70, 964-973. [CrossRef] [PubMed]

156. Magee, R.; Londin, E.; Rigoutsos, I. TRNA-derived fragments as sex-dependent circulating candidate biomarkers for Parkinson's disease. Parkinsonism Relat. Disord. 2019, 65, 203-209. [CrossRef]

157. Hong, C.T.; Hu, H.H.; Chan, L.; Bai, C.-H. Prevalent cerebrovascular and cardiovascular disease in people with Parkinson's disease: A meta-analysis. Clin. Epidemiol. 2018, 10, 1147-1154. [CrossRef]

158. Muqtadar, H.; Testai, F.D.; Gorelick, P.B. The Dementia of Cardiac Disease. Curr. Cardiol. Rep. 2012, 14, 732-740. [CrossRef] 
159. Chen, H.; Zhang, S.M.; Schwarzschild, M.A.; Hernan, M.A.; Willett, W.C.; Ascherio, A. Obesity and the risk of Parkinson's disease. Am. J. Epidemiol. 2004, 159, 547-555. [CrossRef]

160. Simon, K.C.; Chen, H.; Schwarzschild, M.; Ascherio, A. Hypertension, hypercholesterolemia, diabetes, and risk of Parkinson disease. Neurology 2007, 69, 1688-1695. [CrossRef]

161. Dölle, C.; Flønes, I.; Nido, G.S.; Miletic, H.; Osuagwu, N.; Kristoffersen, S.; Lilleng, P.K.; Larsen, J.P.; Tysnes, O.-B.; Haugarvoll, K.; et al. Defective mitochondrial DNA homeostasis in the substantia nigra in Parkinson disease. Nat. Commun. 2016, 7, 13548. [CrossRef]

162. Yu, E.P.K.; Bennett, M.R. The role of mitochondrial DNA damage in the development of atherosclerosis. Free Radic. Biol. Med. 2016, 100, 223-230. [CrossRef] [PubMed]

163. Huang, Y.-P.; Chen, L.-S.; Yen, M.-F.; Fann, C.-Y.; Chiu, Y.-H.; Chen, H.-H.; Pan, S.-L. Parkinson's Disease Is Related to an Increased Risk of Ischemic Stroke-A Population-Based Propensity Score-Matched Follow-up Study. PLoS ONE 2013, 8, e68314. [CrossRef]

164. Liang, H.-W.; Huang, Y.-P.; Pan, S.-L. Parkinson disease and risk of acute myocardial infarction: A population-based, propensity score-matched, longitudinal follow-up study. Am. Hear. J. 2015, 169, 508-514. [CrossRef] [PubMed]

165. Jones, J.D.; Malaty, I.; Price, C.C.; Okun, M.; Bowers, D. Health comorbidities and cognition in 1948 patients with idiopathic Parkinson's disease. Park. Relat. Disord. 2012, 18, 1073-1078. [CrossRef] [PubMed]

166. Wang, X.; Zeng, F.; Jin, W.S.; Zhu, C.; Wang, Q.H.; Bu, X.L.; Luo, H.B.; Zou, H.Q.; Pu, J.; Zhou, Z.H.; et al. Comorbidity burden of patients with Parkinson's disease and Parkinsonism between 2003 and 2012: A multicentre, nationwide, retrospective study in China. Sci. Rep. 2017, 7, 1671. [CrossRef]

167. Peralta, C.; Wolf, E.; Alber, H.; Seppi, K.; Muller, S.; Bosch, S.; Wenning, G.K.; Pachinger, O.; Poewe, W. Valvular heart disease in Parkinson's disease vs. controls: An echocardiographic study. Mov. Disord. 2006, 21, 1109-1113. [CrossRef] [PubMed]

168. Van Camp, G.; Flamez, A.; Cosyns, B.; Weytjens, C.; Muyldermans, L.; Van Zandijcke, M.; De Sutter, J.; Santens, P.; Decoodt, P.; Moerman, C.; et al. Treatment of Parkinson's disease with pergolide and relation to restrictive valvular heart disease. Lancet 2004, 363, 1179-1183. [CrossRef]

169. Whitsett, T.L.; Goldberg, L.I. Effects of levodopa on systolic preejection period, blood pressure, and heart rate during acute and chronic treatment of Parkinson's disease. Circulation 1972, 45, 97-106. [CrossRef]

170. Noack, C.; Schroeder, C.; Heusser, K.; Lipp, A. Cardiovascular effects of levodopa in Parkinson's disease. Parkinsonism Relat. Disord. 2014, 20, 815-818. [CrossRef]

171. Apraxine, M.; Pasquet, A.; Jeanjean, A.P. Pramipexole-Induced Reversible Heart Failure. Mov. Disord. Clin. Pract. 2014, 1, 381-382. [CrossRef]

172. Galassi, G.; Georgoulopoulou, E.; Ariatti, A. Amiodarone neurotoxicity: The other side of the medal. Open Med. 2014, 9, 437-442. [CrossRef]

173. Ishida, S.; Sugino, M.; Hosokawa, T.; Sato, T.; Furutama, D.; Fukuda, A.; Kimura, F.; Kuwabara, H.; Shibayama, Y.; Hanafusa, T. Amiodarone-induced liver cirrhosis and parkinsonism: A case report. Clin. Neuropathol. 2010, 29, 84-88. [CrossRef] [PubMed]

174. Fabiani, G.; Pastro, P.C.; Froehner, C. Parkinsonism and other movement disorders in outpatients in chronic use of cinnarizine and flunarizine. Arq. Neuro-Psiquiatr. 2004, 62, 784-788. [CrossRef] [PubMed]

175. Mukherjee, U.A.; Ong, S.-B.; Hausenloy, D.J.; Ong, S.-G. Parkinson's disease proteins: Novel mitochondrial targets for cardioprotection. Pharmacol. Ther. 2015, 156, 34-43. [CrossRef] [PubMed]

176. Zhang, S.-X.; Zhuang, L.-L.; Liu, J.; Jing, Y.-Y.; Sun, J.; Gong, L.; Liu, X.-Y. The role of Parkin protein in cardiac function and ventricular remodeling in myocardial infarction rats. Eur. Rev. Med. Pharmacol. Sci. 2018, 22, 5004-5013.

177. Kim, J.; Inoue, K.; Ishii, J.; Vanti, W.B.; Voronov, S.V.; Murchison, E.; Hannon, G.; Abeliovich, A. A MicroRNA Feedback Circuit in Midbrain Dopamine Neurons. Science 2007, 317, 1220-1224. [CrossRef]

178. Boštjančič, E.; Brandner, T.; Zidar, N.; Glavač, D.; Štajer, D. Down-regulation of miR-133a/b in patients with myocardial infarction correlates with the presence of ventricular fibrillation. Biomed. Pharmacother. 2018, 99, 65-71. [CrossRef]

179. Yu, Y.; Liu, H.; Yang, D.; He, F.; Yuan, Y.; Guo, J.; Hu, J.; Yu, J.; Yan, X.; Wang, S.; et al. Aloe-emodin attenuates myocardial infarction and apoptosis via up-regulating miR-133 expression. Pharmacol. Res. 2019, 146, 104315. [CrossRef] 
180. Liu, Y.; Li, Y.; Ni, J.; Shu, Y.; Wang, H.; Hu, T. MiR-124 attenuates doxorubicin-induced cardiac injury via inhibiting p66Shc-mediated oxidative stress. Biochem. Biophys. Res. Commun. 2019, 521, 420-426. [CrossRef]

181. Zhao, Y.; Yan, M.; Chen, C.; Gong, W.; Yin, Z.; Li, H.; Fan, J.; Zhang, X.A.; Wang, D.W.; Zuo, H. MiR-124 aggravates failing hearts by suppressing CD151-facilitated angiogenesis in heart. Oncotarget 2018, 9, 14382-14396. [CrossRef]

182. Geng, L.; Liu, W.; Chen, Y. miR-124-3p attenuates MPP+-induced neuronal injury by targeting STAT3 in SH-SY5Y cells. Exp. Biol. Med. 2017, 242, 1757-1764. [CrossRef] [PubMed]

183. Yao, L.; Zhu, Z.; Wu, J.; Zhang, Y.; Zhang, H.; Sun, X.; Qian, C.; Wang, B.; Xie, L.; Zhang, S.; et al. MicroRNA-124 regulates the expression of p62/p38 and promotes autophagy in the inflammatory pathogenesis of Parkinson's disease. FASEB J. 2019, 33, 8648-8665. [CrossRef]

184. Gong, X.; Zhu, Y.; Chang, H.; Li, Y.; Ma, F. Long noncoding RNA MALAT1 promotes cardiomyocyte apoptosis after myocardial infarction via targeting miR-144-3p. Biosci. Rep. 2019, 39. [CrossRef] [PubMed]

185. Huang, S.; Zhang, L.; Song, J.; Wang, Z.; Huang, X.; Guo, Z.; Chen, F.; Zhao, X.-X. Long noncoding RNA MALAT1 mediates cardiac fibrosis in experimental postinfarct myocardium mice model. J. Cell. Physiol. 2018, 234, 2997-3006. [CrossRef]

186. Zhang, Q.-S.; Wang, Z.-H.; Zhang, J.-L.; Duan, Y.-L.; Li, G.-F.; Zheng, D.-L. Beta-asarone protects against MPTP-induced Parkinson's disease via regulating long non-coding RNA MALAT1 and inhibiting $\alpha$-synuclein protein expression. Biomed. Pharmacother. 2016, 83, 153-159. [CrossRef]

187. Chen, Q.; Huang, X.; Li, R. lncRNA MALAT1/miR-205-5p axis regulates MPP(+)-induced cell apoptosis in MN9D cells by directly targeting LRRK2. Am. J. Transl. Res. 2018, 10, 563-572. [PubMed]

188. Gao, L.; Liu, Y.; Guo, S.; Yao, R.; Wu, L.; Xiao, L.; Wang, Z.; Liu, Y.; Zhang, Y. Circulating Long Noncoding RNA HOTAIR is an Essential Mediator of Acute Myocardial Infarction. Cell. Physiol. Biochem. 2017, 44, 1497-1508.

189. Jiang, Y.; Mo, H.; Luo, J.; Zhao, S.; Liang, S.; Zhang, M.; Yuan, J. HOTAIR Is a Potential Novel Biomarker in Patients with Congenital Heart Diseases. BioMed Res. Int. 2018, 2018, 2850657. [CrossRef] [PubMed]

190. Wang, S.; Zhang, X.; Guo, Y.; Rong, H.; Liu, T. The long noncoding RNA HOTAIR promotes Parkinson's disease by upregulating LRRK2 expression. Oncotarget 2017, 8, 24449-24456. [CrossRef]

191. Zhou, F.; Xie, S.; Li, J.; Duan, S. Long noncoding RNA HOTAIR promotes cell apoptosis by sponging miR-221 in Parkinson's disease. RSC Adv. 2019, 9, 29502-29510. [CrossRef]

192. Caudle, W.M.; Bammler, T.K.; Lin, Y.; Pan, S.; Zhang, J. Using 'omics' to define pathogenesis and biomarkers of Parkinson's disease. Expert. Rev. Neurother. 2010, 10, 925-942. [CrossRef] [PubMed]

193. Schapira, A. Mitochondrial dysfunction in neurodegenerative disorders. Biochim. Biophys. Acta (BBA) Bioenerg. 1998, 1366, 225-233. [CrossRef]

194. Chang, D.; Nalls, M.A.; Hallgrimsdottir, I.B.; Hunkapiller, J.; van der Brug, M.; Cai, F.; International Parkinson's Disease Genomics Consortium; 23andMe Research Team; Kerchner, G.A.; Ayalon, G.; et al. A meta-analysis of genome-wide association studies identifies 17 new Parkinson's disease risk loci. Nat. Genet. 2017, 49, 1511-1516. [CrossRef] [PubMed]

195. Kikuchi, T.; Morizane, A.; Doi, D.; Magotani, H.; Onoe, H.; Hayashi, T.; Mizuma, H.; Takara, S.; Takahashi, R.; Inoue, H.; et al. Human iPS cell-derived dopaminergic neurons function in a primate Parkinson's disease model. Nature 2017, 548, 592-596. [CrossRef] [PubMed]

196. Barrett, T.; Wilhite, S.E.; Ledoux, P.; Evangelista, C.; Kim, I.F.; Tomashevsky, M.; Marshall, K.A.; Phillippy, K.H.; Sherman, P.M.; Holko, M.; et al. NCBI GEO: Archive for functional genomics data sets-Update. Nucleic Acids Res. 2013, 41, D991-D995. [CrossRef]

197. Hoss, A.G.; Labadorf, A.; Beach, T.G.; Latourelle, J.C.; Myers, R.H. microRNA Profiles in Parkinson's Disease Prefrontal Cortex. Front. Aging Neurosci. 2016, 8, 36. [CrossRef]

198. Schulze, M.; Sommer, A.; Plötz, S.; Farrell, M.; Winner, B.; Grosch, J.; Winkler, J.; Riemenschneider, M.J. Sporadic Parkinson's disease derived neuronal cells show disease-specific mRNA and small RNA signatures with abundant deregulation of piRNAs. Acta Neuropathol. Commun. 2018, 6, 58. [CrossRef]

199. Pantano, L.; Friedländer, M.R.; Escaramís, G.; Lizano, E.; Pallarès-Albanell, J.; Ferrer, I.; Estivill, X.; Martí, E. Specific small-RNA signatures in the amygdala at premotor and motor stages of Parkinson's disease revealed by deep sequencing analysis. Bioinformatics 2015, 32, 673-681. [CrossRef]

200. Soreq, L.; Salomonis, N.; Bronstein, M.; Greenberg, D.S.; Israel, Z.; Bergman, H.; Soreq, H. Small RNA sequencing-microarray analyses in Parkinson leukocytes reveal deep brain stimulation-induced splicing changes that classify brain region transcriptomes. Front. Mol. Neurosci. 2013, 6, 10. [CrossRef] 
201. Zhang, L.; Hamad, A.; Vausort, M.; Funakoshi, H.; Feldman, A.M.; Wagner, D.R.; Devaux, Y. Identification of Candidate Long Noncoding RNAs Associated with Left Ventricular Hypertrophy. Clin. Transl. Sci. 2014, 8, 100-106. [CrossRef]

202. Zhang, L.; Salgado-Somoza, A.; Vausort, M.; Leszek, P.; Devaux, Y. A heart-enriched antisense long non-coding RNA regulates the balance between cardiac and skeletal muscle triadin. Biochim. Biophys. Acta (BBA) Bioenerg. 2018, 1865, 247-258. [CrossRef] [PubMed]

203. Cheng, J.; Metge, F.; Dieterich, C. Specific identification and quantification of circular RNAs from sequencing data. Bioinformatics 2015, 32, 1094-1096. [CrossRef] [PubMed]

204. Memczak, S.; Jens, M.; Elefsinioti, A.; Torti, F.; Krueger, J.; Rybak, A.; Maier, L.; Mackowiak, S.D.; Gregersen, L.H.; Munschauer, M.; et al. Circular RNAs are a large class of animal RNAs with regulatory potency. Nature 2013, 495, 333-338. [CrossRef] [PubMed]

205. Mollenhauer, B.; Zimmermann, J.; Sixel-Döring, F.; Focke, N.K.; Wicke, T.; Ebentheuer, J.; Schaumburg, M.; Lang, E.; Trautmann, E.; Zetterberg, H.; et al. Monitoring of 30 marker candidates in early Parkinson disease as progression markers. Neurology 2016, 87, 168-177. [CrossRef]

206. Subramanian, A.; Tamayo, P.; Mootha, V.K.; Mukherjee, S.; Ebert, B.L.; Gillette, M.A.; Paulovich, A.; Pomeroy, S.L.; Golub, T.R.; Lander, E.S.; et al. Gene set enrichment analysis: A knowledge-based approach for interpreting genome-wide expression profiles. Proc. Natl. Acad. Sci. USA 2005, 102, 15545-15550. [CrossRef]

207. Kim, S.-Y.; Volsky, D.J. PAGE: Parametric Analysis of Gene Set Enrichment. BMC Bioinform. 2005, 6, 144. [CrossRef]

208. Glaab, E.; Schneider, R. PathVar: Analysis of gene and protein expression variance in cellular pathways using microarray data. Bioinformatics 2011, 28, 446-447. [CrossRef]

209. Lee, E.; Chuang, H.-Y.; Kim, J.-W.; Ideker, T.; Lee, D. Inferring Pathway Activity toward Precise Disease Classification. PLoS Comput. Biol. 2008, 4, e1000217. [CrossRef]

210. Dittrich, M.T.; Klau, G.W.; Rosenwald, A.; Dandekar, T.; Müller, T. Identifying functional modules in protein-protein interaction networks: An integrated exact approach. Bioinformatics 2008, 24, i223-i231. [CrossRef]

211. Kittas, A.; Delobelle, A.; Schmitt, S.; Breuhahn, K.; Guziolowski, C.; Grabe, N. Directed random walks and constraint programming reveal active pathways in hepatocyte growth factor signaling. FEBS J. 2016, 283, 350-360. [CrossRef]

212. Catlett, N.L.; Bargnesi, A.J.; Ungerer, S.; Seagaran, T.; Ladd, W.; Elliston, K.O.; Pratt, D. Reverse causal reasoning: Applying qualitative causal knowledge to the interpretation of high-throughput data. BMC Bioinform. 2013, 14, 340. [CrossRef] [PubMed]

213. Chindelevitch, L.; Ziemek, D.; EnayetAllah, A.; Randhawa, R.; Sidders, B.; Brockel, C.; Huang, E.S. Causal reasoning on biological networks: Interpreting transcriptional changes. Bioinformatics 2012, 28, 1114-1121. [CrossRef] [PubMed]

214. Fakhry, C.T.; Choudhary, P.; Gutteridge, A.; Sidders, B.; Chen, P.; Ziemek, D.; Zarringhalam, K. Interpreting transcriptional changes using causal graphs: New methods and their practical utility on public networks. BMC Bioinform. 2016, 17, 318. [CrossRef] [PubMed]

215. Jaeger, S.; Min, J.; Nigsch, F.; Camargo, M.; Hutz, J.E.; Cornett, A.; Cleaver, S.; Buckler, A.; Jenkins, J.L. Causal Network Models for Predicting Compound Targets and Driving Pathways in Cancer. J. Biomol. Screen. 2014, 19, 791-802. [CrossRef]

216. Edwards, Y.J.K.; Beecham, G.W.; Scott, W.K.; Khuri, S.; Bademci, G.; Tekin, D.; Martin, E.R.; Jiang, Z.; Mash, D.C.; Ffrench-Mullen, J.; et al. Identifying Consensus Disease Pathways in Parkinson's Disease Using an Integrative Systems Biology Approach. PLoS ONE 2011, 6, e16917. [CrossRef]

217. Chandrasekaran, S.; Bonchev, D. A network view on Parkinson's disease. Comput. Struct. Biotechnol. J. 2013, 7, e201304004. [CrossRef]

218. Fujita, K.A.; Ostaszewski, M.; Matsuoka, Y.; Ghosh, S.; Glaab, E.; Trefois, C.; Crespo, I.; Perumal, T.M.; Jurkowski, W.; Antony, P.M.A.; et al. Integrating Pathways of Parkinson's Disease in a Molecular Interaction Map. Mol. Neurobiol. 2013, 49, 88-102. [CrossRef]

219. Santiago, J.A.; Potashkin, J.A. Integrative network analysis unveils convergent molecular pathways in Parkinson's disease and diabetes. PLoS ONE 2013, 8, e83940. [CrossRef]

220. Fu, L.M.; Fu, K.A. Analysis of Parkinson's disease pathophysiology using an integrated genomics-bioinformatics approach. Pathophysiology 2015, 22, 15-29. [CrossRef] 
221. Wang, Q.; Zhang, Y.; Wang, M.; Song, W.M.; Shen, Q.; McKenzie, A.; Choi, I.; Zhou, X.; Pan, P.-Y.; Yue, Z.; et al. The landscape of multiscale transcriptomic networks and key regulators in Parkinson's disease. Nat. Commun. 2019, 10, 5234. [CrossRef]

222. Riley, B.E.; Gardai, S.J.; Emig-Agius, D.; Bessarabova, M.; Ivliev, A.E.; Schule, B.; Alexander, J.; Wallace, W.; Halliday, G.M.; Langston, J.W.; et al. Systems-based analyses of brain regions functionally impacted in Parkinson's disease reveals underlying causal mechanisms. PLoS ONE 2014, 9, e102909. [CrossRef] [PubMed] 